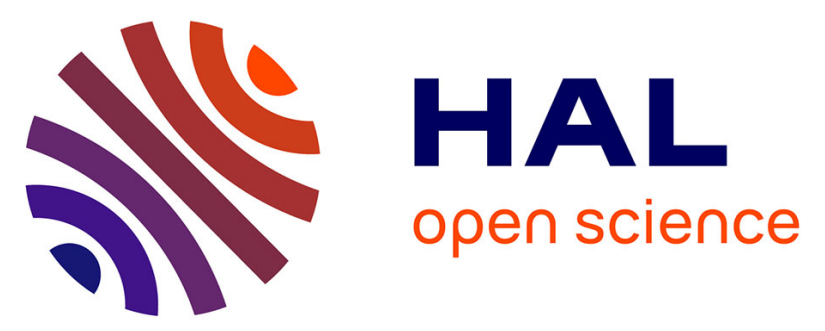

\title{
Impacts of oxygenated compounds concentration on sooting propensities and soot oxidative reactivity: Application to Diesel and Biodiesel surrogates
}

Johnny Abboud, Julie Schobing, Guillaume Legros, Jérôme Bonnety, Valerie Tschamber, Alain Brillard, Gontrand Leyssens, Vincent Lauga, Eduard Emil Iojoiu, Patrick da Costa

\section{To cite this version:}

Johnny Abboud, Julie Schobing, Guillaume Legros, Jérôme Bonnety, Valerie Tschamber, et al.. Impacts of oxygenated compounds concentration on sooting propensities and soot oxidative reactivity: Application to Diesel and Biodiesel surrogates. Fuel, 2017, 193, pp.241 - 253. 10.1016/j.fuel.2016.12.034 . hal-01427345

\section{HAL Id: hal-01427345 \\ https://hal.sorbonne-universite.fr/hal-01427345}

Submitted on 5 Jan 2017

HAL is a multi-disciplinary open access archive for the deposit and dissemination of scientific research documents, whether they are published or not. The documents may come from teaching and research institutions in France or abroad, or from public or private research centers.
L'archive ouverte pluridisciplinaire HAL, est destinée au dépôt et à la diffusion de documents scientifiques de niveau recherche, publiés ou non, émanant des établissements d'enseignement et de recherche français ou étrangers, des laboratoires publics ou privés. 


\title{
Impacts of oxygenated compounds concentration on sooting
}

\section{propensities and soot oxidative reactivity: application to Diesel}

\author{
and Biodiesel surrogates
}

Johnny Abboud ${ }^{\text {a }}$, Julie Schobing ${ }^{\mathrm{b}}$, Guillaume Legros ${ }^{\mathrm{a}}$, Jérôme Bonnety ${ }^{\mathrm{a}}$, Valerie Tschamber ${ }^{\mathrm{b}}$, Alain Brillard ${ }^{\mathrm{b}}$, Gontrand Leyssens ${ }^{\mathrm{b}}$, Vincent Lauga ${ }^{\mathrm{c}}$, Eduard Emil Iojoiu ${ }^{\mathrm{c}}$, Patrick Da Costa $^{\mathrm{a}}$

a Sorbonne Universités, UPMC, Univ. Paris 6, CNRS, UMR 7190, Institut Jean Le Rond d'Alembert, 2 place de la gare de ceinture, 78210 Saint-Cyr-L'Ecole, France

${ }^{\mathrm{b}}$ Laboratoire Gestion des Risques et Environnement, Université de Haute Alsace, 3 bis rue A. Werner, 68093 Mulhouse cedex, France

${ }^{\mathrm{c}}$ Renault Trucks - Volvo Group Trucks Technology - Powertrain Engineering Lyon, 99 route de Lyon - 69806 Saint-Priest Cedex, France

\section{Abstract}

The aim of this paper is to evaluate the effect of the oxygenated compounds concentration on sooting propensities of Diesel and Biodiesel surrogates and to investigate the oxidative reactivity of soot obtained by combustion of these surrogates using an atmospheric axisymmetric co-flow diffusion flame burner. Methyl decanoate (MD) concentrations from 3 to $30 \%$ (in mole \%) are added to a Diesel surrogate made up of a binary mixture of $70 \%$ of n-decane and $30 \%$ of $\alpha$-methylnaphthalene $(\alpha-M N)$. The sooting propensities of these mixtures are estimated through the Yield Sooting Indices (YSIs) in methane diffusion flames doped with 35,000 ppm of surrogate vapors. The characteristics of the soot volume fraction are extracted using the light extinction method (LEM). Additionally, soot generated from the combustion of the model Diesel and Biodiesel fuels were collected, sampled and characterized using physico-chemical techniques. MD addition is found to reduce sooting tendencies. This decrease is more pronounced when the concentration of oxygenate additives 
increases. On another side, the oxidative reactivity of soot generated from the diffusion flame burner is found to decrease when the Biodiesel percentage increases. Furthermore, soot generated from the combustion of Diesel and Biodiesel surrogates exhibited different behaviors. Biodiesel-derived soot particles were smaller and less reactive than Diesel-derived ones, the latter displaying less ordered graphite-like structures and higher amorphous carbon concentration.

Key words: Diffusion flame, Yield Sooting Index, Oxygenated compound, Diesel, Biodiesel, Surrogate, Soot, Reactivity.

\section{Introduction}

The use of biofuels regularly increases being one of the best contributors to the reduction of greenhouse gases (GHG) emissions. Such products are indeed well known for their renewability and their ability to represent a carbon dioxide-cycle during their combustion through photosynthetic ways [1]. Biodiesel is a synthetic Diesel-like fuel produced through the transesterification of triglycerides contained in vegetable or animal fats [2]. It can be used blended with conventional Diesel or not [2,3]. The impact of the combustion of Biodiesel and Biodiesel blends in Diesel engines on emissions, especially of particulate matter (PM), received a special attention for the past few years [4-7]. Soot particles represent a significant component of the PM emitted by engines [8]. These emissions contribute to smog and are suspected to affect local climate [9]. Furthermore, the harmfulness of soot particles on human health is mainly attributed to adsorbed ones. Soot particles may contain many chemical species: heavy metals, inorganic compounds as well as organic species such as polycyclic aromatic hydrocarbons (PAHs) [10,11]. The latter are classified as carcinogenic, mutagenic or toxic for the reproduction (CMR) by the International Agency for research on Cancer (IARC) [12]. 
The mechanisms governing soot formation and oxidation in Diesel engines during fuel combustion are complex and their evaluation is difficult. For a better understanding of fundamental chemical and physical factors leading to soot production, laboratory scale laminar non-premixed flames are usually used. Studies on diffusion flames at a laboratory scale are indeed realized in order to evaluate the sooting tendencies of various model fuels using the Smoke Point as an index to assess soot propensity [13-15]. The previous results concerning the impact of oxygenated additives on sooting tendencies of surrogate fuels proved that these sooting tendencies monotonically decrease with increasing oxygenate concentration in the fuel mixture. Three main factors have been identified which explain this relationship: the dilution effect of the base fuel when adding oxygenated additives [16,17], the reduction of the mole fractions of key intermediate products which play an important role in the formation of soot precursors [18] and the formation of oxidant radicals which enhance more soot oxidation than soot formation [19]. Furthermore, McEnally and Pefferle [20] measured the sooting tendencies of 186 oxygenated hydrocarbons in terms of the Yield Sooting Index (YSI). These authors found that direct chemical effects associated with the structure of additives mainly govern the measured trends. At a given carbon number, the YSI increases in the following order: ethers $<$ primary alcohols $\approx$ n-alkanes $<$ secondary alcohols. They also found that the molecular structure of ester compounds plays a key role and has a higher effect on soot elimination when compared to carbonyl compounds with a single oxygen atom like alcohols and ethers.

The structure, the composition and the morphology of soot largely depend on their origin and their production conditions. This fact has triggered a debate in order to highlight which of these factors most contribute and affect soot reactivity. Many studies have correlated soot characteristics and reactivity with the internal structure (nanostructure) of its primary particles, which depends, among others, on the fuel type and origin [21,22]. As an illustration, 
Vander Wal and Tomasek [23] showed that soot nanostructure mainly depends on the synthesis conditions like temperature, time and nature of the fuel. They also evoked the dependence of the reactivity on the relative number and accessibility of potential reactive carbon edge sites. Other studies emphasized the role of the composition of tested fuels, more specifically the impact of oxygenate additives on soot formation and reactivity. For instance, Soeong and Boehman [19] suggested that the earlier the soot is formed in a given flame, the less reactive it will be when it escapes from the flame tip. They also found that the surface oxygen content is proportional to the soot oxidative reactivity and may be the main factor for oxidation reactivity of oxygenated soot. On the other hand, Ghiassi et al. [24] studied the impact of n-butanol addition at different mole fractions $(10 \% / 30 \% / 60 \%)$ on a Diesel surrogate, i.e. n-dodecane. When quantifying the soot stability during an oxidation process, they found that the oxidation reactivity increases with increasing alcohol percentage up to $30 \%$. After this level, they noticed a decrease of activity at $60 \%$ n-butanol even though the amount of soot produced was decreasing. They attributed this non-monotonicity of the soot reactivity to dissimilar nanostructures. In fact, soot derived from $30 \%$ n-butanol has shorter carbon segments while that derived from $60 \%$ n-butanol has a higher amount of layer planes with high curvature. This latter nanostructure was supposed to be less active than the first one. Barrientos et al. [25] studied soot samples generated from the combustion of various methyl esters, n-alkanes, Biodiesel and Diesel fuels in laminar co-flow diffusion flames via thermogravimetric analysis (TGA) and Raman spectroscopy. They found that ester compounds contained in Biodiesel have an impact on soot oxidative reactivity and soot characteristics. Along the combustion of shorter alkyl chains of methyl esters, soot particles exhibited higher soot reactivity and lower structural ordered. The authors also found that the impact of fuel-bound oxygen on the soot reactivity became less significant as the carbon chain length increases. Similar studies were performed in the case of real soot produced on 
test bench. Song et al. [26] studied the reactivity of soot derived from the combustion of neat Biodiesel (B100), ultra-low sulfur Diesel (ULSD), Fischer-Tropsch synthetic Diesel fuel (FT100) and ULSD blended with 20\% Biodiesel. In order to explain the high reactivity found in B100 derived soot, the authors speculated that B100 derived soot undergoes a unique oxidation process called "internal burning" leading to a total destruction of the core and a possible formation of graphene layer structures. It was also discussed that not only the initial nanostructure determined the reactivity of soot but also the degree of internal structure change during oxidation had a strong influence on this soot reactivity. In another study [27], it was found that the abundance on the soot surface of oxygen functional groups could enhance soot reactivity. This incorporation of oxygen due to the use of Biodiesel may be more crucial than the initial structure and pore size distribution of soot particles in terms of soot oxidative reactivity. In addition to the high oxygen content, Löpez-Suarez et al. [28] attributed the higher reactivity of B100 soot to the presence of metallic impurities which can play a catalytic role.

In the present work, Diesel and Biodiesel surrogates are incorporated into the fuel stream burning in a laminar co-flow diffusion flame which allows strictly controlled experimental conditions. The impact of various oxygenated compounds like esters on both sooting tendencies and soot oxidative reactivity can thus be assessed. The sooting tendency of selected surrogates is measured in terms of the yield sooting indices (YSIs) in methane diffusion flames doped with the vapors of tested fuels. The structure and the oxidative reactivity of soot samples generated from the combustion of these surrogates are investigated using temperature-programmed oxidation (TPO), thermogravimetric analysis (TGA) and Raman spectroscopy. These results are compared with those concerning the reactivity of soot generated by a real Diesel engine. 


\section{Experimental procedure}

\subsection{Burner configuration}

Santoro et al. [29] established non-premixed diffusion flames over an axisymmetric co-flow burner. This configuration allowed McEnally et al. [20,30] to extract YSIs values for a wide range of fuels. Kashif et al. [31] proposed an experimental procedure based on previous investigations in order to measure the volume fraction of soot particles emitted by primary reference fuels using the laser extinction method (LEM).

In the burner, the fuel stream flows through a vertical axial brass duct, which has an effective $11 \mathrm{~mm}$ injection diameter $d_{F}$. The co-flowing oxidizer mixture is introduced into a concentric brass cylinder of $102 \mathrm{~mm}$ inner diameter through four bend canals thus favoring the homogeneity of the final mixture. Gases flow rates are controlled by mass flows type Bronkhorst EL-FLOW. Finally, a combination consisting of perforated copper plate, glass beads and ceramic cell with honeycomb shape of $1.22 \mathrm{~mm}$ in size, allows the rectification of oxidant flows and ensures an up-laminar-flow through the burner.

The symmetry axis is $(\mathrm{Oz})$ and its origin is located at the burner tip, defining the height above the burner (HAB). The cross-stream coordinate is $r$, which is the distance from the symmetry axis. The inner radius of the axial duct is $R=d_{F} / 2$.

\subsection{Flow control}

Atmospheric-pressure co-flow laminar non-premixed flames were generated with a burner in which the reactants come from a high-purity gas cylinder $\left(\mathrm{CH}_{4}\right.$ and or $\mathrm{N}_{2} ; 99.9 \%$ stated purities) and a compressor (air). Figure 1 describes the experimental setup.

After establishing the vacuum in the whole line $(1,2,10)$, the liquid fuel whose tendency will be quantified is filled in through the padding valve (5). The liquid fuel which is stored in a specific fuel tank (3) is then pushed away by an inert gas - argon - and flows through a 
Coriolis mass flow controller (6). The liquid fuel is then vaporized and mixed with a carrier gas - methane - using a Bronkhorst controlled evaporation and a mixing (CEM) system (7). The gaseous mixture is finally carried out through a heated line (8) to the inner central duct of the burner. A heating wire is indeed wrapped around this duct inside the burner up to the honeycomb inlet. From the evaporator to the burner tip, the different duct connections are thermally insulated and the walls along the fuel line are maintained at a temperature of $180{ }^{\circ} \mathrm{C}$ in order to prevent the tested fuels from condensing.

A thermocouple inserted in the central tube at the bottom end of the burner measures the temperature of the gaseous mixture in order to be sure that no condensation occurs. Furthermore, the possible condensed fuel can be flushed through a valve located at the very bottom of the burner. No fuel droplet leaked through the valve during the flush purging which was performed after each experiment.

\subsection{Tested fuels}

In the present work, due to the complex Diesel composition, a Diesel surrogate named Aref and consisting of a binary mixture of $70 \%$ (in mole $\%$ ) of $n$-decane and $30 \%$ of $\alpha$ methylnaphthalene $(\alpha-\mathrm{MN})$ was chosen as model fuel. This surrogate was previously used in the literature in order to simulate the combustion process which occurs in Diesel engines and the reproduction of the soot formation process which occurs during the combustion of commercial Diesel [32-35]. Methyldecanoate $\left(\mathrm{C}_{11} \mathrm{H}_{22} \mathrm{O}_{2}\right)$ has been selected as the oxygenate additive and has been added to the reference surrogate (Aref) in proportions of 3, 7, 15 and 30 mole $\%$ in order to obtain the corresponding Biodiesel surrogates named MD3, MD7, MD15 and MD30 respectively. Table 1 presents the different surrogates used in the present study with their chemical composition. Soot particles generated from the combustion of these 
surrogates using the co-flow diffusion flame burner will be named Aref soot, MD3 soot, MD7 soot, MD15 soot and MD30 soot, respectively.

\subsection{Methodology for the evaluation of sooting tendencies of Diesel and Biodiesel surrogates}

\subsubsection{Light extinction measurement (LEM) diagnostics and soot volume fraction} measurements

It has already been shown that the light extinction measurement (LEM) technique provides a good resolution in both time and space, which allows a better tracking of soot formation in diffusion flames [36]. The optical diagnostic contributing to the measurement of twodimensional soot volume fractions will here be based on this technique. The system consists of a continuous laser beam whose power is equal to $100 \mathrm{~mW}$ (11) and with a wavelength of $645 \mathrm{~nm}(-5 /+7 \mathrm{~nm})$. A complex setup with collimator optical lenses and mirrors is then used to shrink the original laser beam $(13,14)$. Once the flame passed through, the beam is decollimated through a specific lens (16), which will be filtered and then collected by a camera (17). Finally, a frame grabber records the frames captured by the camera on a computer.

In order to have a spatial resolution of $50 \mu \mathrm{m}$ for the LEM projected data over the $70 \mathrm{~mm}$ diameter investigated, an optical arrangement is needed leading to the construction of the matrix $1312 \times 1082$ pixels. In this arrangement, the Photon Focus MV1 12-bit progressive scan monochrome camera is equipped with a conventional lens, with a narrow band filter centered at $645 \mathrm{~nm}( \pm 2 \mathrm{~nm})$ and with a bandwidth at one-half the transmissivity maximum of $20 \mathrm{~nm}$. Further details about this technique can be found in [37].

In order to compute the extinction measurement on every pixel, a sequence of four frames is requested: 
- Frame with flame on and laser established (attenuated laser light intensity, $I^{l}{ }_{\lambda}$ ),

- Frame with flame established and laser off (background and flame emission intensity, $\left.I^{f, b}{ }_{\lambda}\right)$,

- Frame without flame but laser on (unattenuated laser light intensity, $I_{\lambda}{ }_{\lambda}$ ),

- Frame without flame and laser off (background intensity, $I_{\lambda}^{b}$ ).

For a given $z j$ height above the burner (HAB) and according to the Beer-Lambert law, the monochromatic transmission for a given radius $r$, measured in pixels, is related to the local extinction coefficient $k$ according to the Eq. 1:

$$
\log \left(\frac{l^{\prime} I^{f, b}}{I^{0} I^{b}}\right)=\int_{0}^{L} \quad \text { ext }\left(r i, z^{j}\right) d s
$$

However, as a line-of-sight technique, LEM needs to be combined with a subsequent deconvolution to infer the local extinction coefficient distribution. Many numerical studies have been developed for this purpose [38-40]. Once the adjustments of parameters are done, Mie's theory is applied in order to calculate the soot volume fraction of soot particles from the field distribution of $k^{e x t}(r i, z j)$, assuming that the soot particles are in the Rayleigh limit:

$$
f v(r i, z)=\frac{{ }^{e x t}(r i, z j)}{6 E(m)}
$$

where $E(m)$ is a function of the complex soot refractive index. In the present study, its value is taken equal to 0.27 based on the work of Kashif et al. [31].

\subsubsection{Quantifying sooting propensities to calculate the Yield Sooting Index (YSI)}

In order to evaluate the apparatus-independent Yield Sooting Index (YSI) of tested Diesel and Biodiesel surrogates, the maximum soot volume fraction $f_{v, \max }=\max \left\{\mathrm{fv}\left(\mathrm{r}, \mathrm{Z}_{\text {meas }}\right) \mid \mathrm{r} \in[0, \mathrm{R}]\right\}$ is measured in diffusion flames burning with co-flowing air which are doped at a given 
concentration with the vapor of the tested surrogate (methane), as reported by McEnally and Pfefferle [30]. At a fixed height $\mathrm{Z}_{\text {meas }}$ above the burner, the YSI is calculated using Eq. 3:

$$
Y S=C f_{v, \text { max }}+D
$$

where $C$ and $D$ are apparatus-specific parameters which are determined by arbitrary YSI values attributed to two reference fuels, namely n-heptane and isooctane as reference fuels: 0 and 48.6, respectively.

\subsubsection{Experimental parameters: flame conditions and soot sampling}

Table 2 shows the experimental parameters that were kept constant throughout the present study.

The co-flowing oxidizer stream consists of filtered laboratory compressed air. For YSIs measurements, the nominal flow rates were kept constant at $210 \mathrm{~cm}^{3} / \mathrm{min}$ for carrier gas (100 $\left.\% \mathrm{CH}_{4}\right)$ and $60,000 \mathrm{~cm}^{3} / \mathrm{min}$ for air.

The temperature of the heated lines was kept at $180{ }^{\circ} \mathrm{C}$ in order to prevent variations of the rate of tested surrogate vapour along the fuel line. Methane flames were doped with the vapours of different blends of Diesel and Biodiesel surrogates with flow rates corresponding to vapour fractions greater than $35,000 \mathrm{ppm}\left(X_{v a p}=3.5 \times 10^{-2}\right.$ mole fraction).

For the soot sampling stage, a carrier gas was diluted with nitrogen $\left(30 \% \mathrm{CH}_{4}, 70 \% \mathrm{~N}_{2}\right)$. This gaseous mixture is then mixed with vapors of different surrogates and then carried along a heated line up to the central burner channel. The dilution is here required in order to bring the concentration of fuel vapors close to the limits of the smoke point, which leads to the emission of soot particles when opening the flames. Soot samples were collected in the post flame region by suction with a pump on a glass microfiber filter $(\varnothing=110 \mathrm{~mm})$ placed in a glass enclosure and isolated from the surrounding atmosphere. Soot were collected every 45 
min for each surrogate sample and then placed in glass vials stored in a desiccator at room temperature for further characterizations.

\subsection{Soot particles characterization}

\subsubsection{Laser granulometry}

Measurements of particle size distributions of soot aggregate particles were carried out in FRITSCH laser particle sizers ANALYSETTE 22 Nano Tec plus, under wet dispersion in which water was used as a suitable liquid. The sample was continuously recirculated and dispersed in a closed circulatory system unit. For the support of the dispersion process, an integrated ultrasonic generator was used whose intensity is adjustable via an operating software. The system provides continuous feedback about the already added soot sample amount and indicates when $10 \%$ of sample dilution is mitigated.

\subsubsection{Elemental analysis: $C H O N S+I C P$}

Elemental soot composition was measured by CHONS and inductively coupled plasma (ICP) for phosphorus (P) content.

\subsubsection{Raman spectroscopy}

Raman spectroscopy measurements were realized using a micro-Raman system (Horiba Jobin Yvon HR $800 \mathrm{UV}$ ) with green sourced laser excitation at $532 \mathrm{~nm}$. The output power was chosen at $0,1 \mathrm{~mW}$ in the scanning range of $800-3500 \mathrm{~cm}^{-1}$. The spectrometer includes a grating with 600 grooves $\mathrm{mm}^{-1}$ and a CCD detector with $50 \times$ magnification objective lens.

\subsubsection{Thermogravimetric analysis (TGA)}


Two different thermogravimetric analyses (TGA) were performed on a TA Q500 apparatus. TGA under air up to $700{ }^{\circ} \mathrm{C}$ were performed in order to measure the ash content. TGA under nitrogen up to $400{ }^{\circ} \mathrm{C}$ with a $4 \mathrm{~h}$ stage were performed in order to evaluate the volatiles content. Each TGA was performed with about $5 \mathrm{mg}$ of soot and with a heating ramp of 5 ${ }^{\circ} \mathrm{C} / \mathrm{min}$.

\subsubsection{Temperature Programmed Oxidation (TPO)}

The soot reactivity was studied performing tests under a temperature program oxidation (TPO) and under different atmospheres: $9 \%$ b.v. $\mathrm{O}_{2} / \mathrm{Ar}, 400$ ppmv $\mathrm{NO}_{2}$ in $\mathrm{N}_{2}, 400$ ppmv $\mathrm{NO}_{2}$ $+10 \%$ b.v. $\mathrm{O}_{2}$ in $\mathrm{N}_{2}$ or 400 ppmv $\mathrm{NO}_{2}+10 \%$ b.v. $\mathrm{O}_{2}+10 \%$ b.v $\mathrm{H}_{2} \mathrm{O}$ in $\mathrm{N}_{2}$.

TPOs using only $\mathrm{O}_{2}\left(9 \%\right.$ b.v. $\left.\mathrm{O}_{2} / \mathrm{Ar}\right)$ were performed in a $\mathrm{U}$-shaped quartz reactor (internal diameter $8 \mathrm{~mm}$ ), the soot sample building a fixed bed of width approximately equal to $2 \mathrm{~mm}$, on a porous frit. $5 \mathrm{mg}$ of soot sample were deposited inside the reactor placed in a thermally isolated furnace and flushed with argon (Ar) at room temperature for approximately 15 minutes. The total flow rate through the reactor was $15 \mathrm{Nl} / \mathrm{h}$. Samples were then heated up to $800^{\circ} \mathrm{C}$ with a $10{ }^{\circ} \mathrm{C} / \mathrm{min}$ heating ramp. The temperature was monitored by a K-type thermocouple located in a thermowell centered in the particle bed. Gas mixtures were produced using calibrated Brooks 5850TR mass flow controllers. Concentrations of $\mathrm{CO}, \mathrm{CO}_{2}$, $\mathrm{NO}$ and $\mathrm{NO}_{2}$ were measured in the outlet gases by an analyzer (Siemens Ultramat6).

TPOs under a gas mixture composed of $\mathrm{NO}_{2}, \mathrm{NO}_{2}+\mathrm{O}_{2}$ or $\mathrm{NO}_{2}+\mathrm{O}_{2}+\mathrm{H}_{2} \mathrm{O}$ were performed using a tubular fixed bed reactor (internal diameter $16 \mathrm{~mm}$ ) (Table 3). All gases were injected through different mass flow meters (Brooks 5850S and Brooks Delta II). The water vapor was introduced using a liquid mass flow meter (Brooks Flomega 5881) followed by an evaporator. The total flow rate through the reactor was $90 \mathrm{Nl} / \mathrm{h}$. The temperature was measured by a thermocouple (K-type) located in the soot bed. $15 \mathrm{mg}$ of carbon sample was diluted in $200 \mathrm{mg}$ of $\mathrm{SiO}_{2}$ in order to avoid heat transfer and reactor clogging. The reactive gas flow was 
injected at ambient temperature. Then the temperature was increased up to $700{ }^{\circ} \mathrm{C}$ with a 5 ${ }^{\circ} \mathrm{C} / \mathrm{min}$ heating ramp. The outlet gas was analyzed using an infrared Rosemount Xstream analyzer in order to quantify the outlet $\mathrm{NO}, \mathrm{NO}_{2}, \mathrm{CO}$ and $\mathrm{CO}_{2}$ molar fractions.

The reactivity of the burner soot will be compared to one real Diesel Soot, denoted as B7BM-CA soot.

From each experiment, the carbon specific oxidation rate $\left(\mathrm{V}_{\mathrm{spec}}\right.$ in $\mathrm{mg} / \mathrm{s} / \mathrm{g}_{\mathrm{c}}$ ini $)$ was calculated from $\mathrm{CO}$ and $\mathrm{CO}_{2}$ emissions ( $\mathrm{X}_{\mathrm{CO}}$ and $\mathrm{X}_{\mathrm{CO} 2}$ in ppm) using Eq. 4:

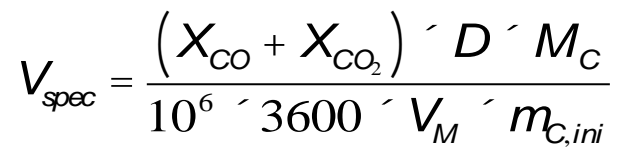

Where $\mathrm{X}_{C O}$ : molar fraction of $\mathrm{CO}(\mathrm{ppmv})$,

$\mathrm{X}_{\mathrm{CO} 2}$ : molar fraction of $\mathrm{CO}_{2}(\mathrm{ppmv})$,

$D$ : flow rate $(\mathrm{Nl} / \mathrm{h})$,

$M c$ : molar mass of carbon in $\left(\mathrm{mg} \cdot \mathrm{mol}^{-1}\right)$,

$V_{M}:$ molar volume $=22.4(\mathrm{~L} / \mathrm{mol})$,

$m_{C, \text { ini }}$ initial carbon mass introduced $(\mathrm{g})$.

\subsection{Soot production on vehicle in real driving conditions}

The B7-BM-CA soot was obtained using a Medium-Duty truck (19T Volvo truck) equipped with an 8L Diesel engine and an EuroVI after treatment system composed of a Diesel oxidation catalyst (DOC), a Diesel particulate filter (DPF) and a selective catalytic reduction system (SCR). The production of real soot was operated in real driving conditions by the combustion of a standard EuroVI fuel (EN 590) blended with 7\% (in volume) of rapeseed methyl ester (FAME). Driving was indeed performed on a city-distribution low loaded cycle (in winter conditions, ambient temperatures between 2 and $15^{\circ} \mathrm{C}$ ), with an average speed of $25 \mathrm{~km} / \mathrm{h}$. Under such driving conditions, the low exhaust temperature linked to this low load cycle reduces the passive soot regeneration and allows a maximal soot collection in the Diesel Particulate Filter (DPF). Once this DPF was loaded at the targeted value, it was 
removed and soot were collected from the DPF under temperatures between 2 and $15{ }^{\circ} \mathrm{C}$ (as soot loading was performed in winter conditions), blowing the DPF during 15 minutes using a pneumatic cleaner (compressed air). Soot samples were then transferred and stored in an appropriate closed bowl for further characterizations.

\section{Results and discussion}

\subsection{Oxygenate blending effect on sooting tendencies of Diesel surrogates}

Figure 2 displays the soot volume fraction fields $f v(p p m)$ in pure methane flames doped with a vapor of tested surrogates. These fields show that the peak of soot volume fraction in the flame tends to decrease as the addition of the oxygenated compound (MD) increases from 3 to $30 \%$.

Furthermore, Figure 3 shows the YSIs associated to the different surrogates with the same vapor mole fraction $X_{v a p}=3.5 \times 10^{-2}$ in the same diffusion flame conditions.

As expected, the highest YSI value is obtained for the Aref surrogate, while the lowest value is obtained after adding $30 \%$ of the oxygenated compound methyldecanoate MD30. This is in agreement with the literature review [16-20,41]. This highest soot reduction observed when MD is used as an additive in the Diesel reference fuel surrogate Aref can mainly be linked to the dilution effect, which replaces highly sooting components $(\alpha-\mathrm{MN})$ (which are well known for the promotion of soot formation) by less sootier components like paraffinic chains, whatever the oxygen concentration in the MD [16,17]. Moreover, adding oxygenated groups like esters were found to reduce the sooting tendency of the base fuel due to chemical effects. In fact, two hypotheses could be posed in order to explain the decrease of soot production in the non-premixed methane flame when using an oxygenated fuel (Figure 2 and Figure 3). The first hypothesis highlights the reduction of soot precursor formation (nuclei). According to Lin et al [42], the pyrolysis of fuel composed of oxygenated species, such as alkylester or 
alkyl radicals, present in the Biodiesel surrogates considered in the present study, induces a higher $\mathrm{CO}$ production. As $\mathrm{CO}$ does not decompose during further pyrolysis, the amount of carbon which can contribute to the inception of soot precursors is reduced. The second hypothesis evokes a difference in soot formation pathways leading to more abundant radical species, such as $\mathrm{O}$ and $\mathrm{OH}$, adding the oxygenate compounds [19]. The higher $\mathrm{O}$ content in soot composition, with increasing Biodiesel surrogate fraction, improves the soot oxidation process in the flame as it is observed that, in co-flow diffusion flames, the soot particle inception and subsequent coagulation and growth are followed by oxidation [43].

\subsection{Particle size distribution}

Figure 4 shows the size distribution of soot particles aggregates of different soot samples. As may be seen, the soot samples have different size distributions. The B7-BM-CA soot generated from Diesel engine has the narrowest particle size distribution and presents only one peak centered on particles whose diameter is close to $4,5 \mu \mathrm{m}$. On the other hand, soot generated from the burner (Aref soot, MD7 soot and MD30 soot) present a bimodal and larger distribution than the B7-BM-CA soot. Moreover, the Aref soot has the widest particle size distribution among soot generated from the burner, with a majority of particles having a diameter equal to $10 \mu \mathrm{m}$. A smaller peak centered at $2,5 \mu \mathrm{m}$ is also observed. When increasing the percentage of Biodiesel surrogate, the distribution of particle aggregates is shifted to smaller diameters and the distribution between the two peaks is reversed so that the size of soot aggregates of MD30 soot is centered on particles with diameter size equal to $2 \mu \mathrm{m}$ for the first peak, and at $7 \mu \mathrm{m}$ or the second peak. Finally, for the MD7 soot, the two peaks are centered at 3 and $6 \mu \mathrm{m}$ with an almost identical distribution. The decrease in particle size distribution by adding oxygenated compound to the reference Diesel surrogate Aref, correlates well with the results of soot volume fraction and sooting tendencies of surrogates 
discussed in section 3.1. In fact, many explanations can be evoked in order to explain the reduced size of soot particles. The first one underlines the presence of higher percentages of radical species when adding methyldecanoate in the Biodiesel surrogates, which leads to a more significant soot oxidation process. The second one highlights the role of the dilution effect which reduces the concentration of surface growth species like acetylene and PAH and contributes to a smaller growth of particle size.

\subsection{Soot composition}

Table 4 presents the composition of the different soot. It can be seen that the carbon content increases with the MD concentration. This trend is in agreement with the addition of $\mathrm{C}$ in the surrogate via the addition of methyldeconoate $\left(\mathrm{C}_{11} \mathrm{H}_{22} \mathrm{O}_{2}\right)$. On the contrary, oxygen content decreases with the MD concentration. The low oxygen content obtained with the soot generated from the burner can be explained by a higher soot oxidation on the soot formation ratio in the flame when the MD concentration increases. The oxidation of soot seems to become more important when oxygenate compounds are added to the initial Diesel surrogate. No significant change is observed in the hydrogen concentration. According to their production mode, Aref soot, MD7 soot and MD30 soot have a very low ash content $(<1 \%)$. In agreement with the literature [28], B7-BM-CA soot present a high oxygen content (almost $12 \%)$ and a significant concentration of inorganic compounds (14.77\% of ash) like calcium (3.02\%), zinc $(1.56 \%)$ and phosphorus $(0.79 \%)$.

SOF content of Aref soot, MD7 soot and MD30 soot also seems to be linked to the MD percentage: the higher is the MD concentration, the lower is the SOF content (Table 4 and Figure 5Figure 5). This can be explained by the dilution phenomenon. It is noteworthy that all the samples have a SOF percentage in the same order, when produced on a test bench or in the burner flame. Figure 5 presents the weight loss for the four soot samples with respect to time 
during TGA experiments under $\mathrm{N}_{2}$. It can be seen that during the $4 \mathrm{~h}$ stage ( $1 \mathrm{~h}$ shown), Aref soot, MD7 soot and MD30 soot present no loss of weight unlike B7-BM-CA soot. Biodiesel soot is oxidizing under $\mathrm{N}_{2}$ because of its high oxygen content. On the contrary, Aref soot, MD7 soot and MD30 soot, with their lower oxygen content, do not oxidize.

\subsection{Raman spectra analysis}

Figure 6 shows, as an example, the observed Raman spectrum of Aref soot collected from the burner.

As reported by Sadezky et al. [44] Raman spectra analysis by 5-band curve fitting method of soot samples and related carbonaceous materials consists of a combination of four Lorentzianshaped bands (G, D1, D2, D4) at about 1580, 1350, 1620 and $1200 \mathrm{~cm}^{-1}$, respectively, with a Gaussian-shaped band D3 at $1500 \mathrm{~cm}^{-1}$. The G-band refers to an ideal graphitic structure. In fact, the higher the gap between the G-band and the ideal graphite $\left(1580 \mathrm{~cm}^{-1}\right)$, the smaller are the graphite sheets in the soot structure and the lower is the degree of organization of these sheets [45]. Among the whole defective D-bands observed, D1 $\left(1350 \mathrm{~cm}^{-1}\right)$ is the most intense which implies the presence either of a disordered graphitic lattice or of hetero elements. In our study, the D1-band is due to this disorder, as a consequence, for instance, of the graphene layer edges as the surrogate used for generating soot is hetero element free. The D3-band represents the amorphous carbon [46-48], while a lower intensity of the D-band indicates a higher disorder in the soot $[48,49]$. In Raman spectra, the ratio between the D-bands and the G-band intensities $\left(I_{D} / I_{G}\right)$ is related to the structural defects in the basal plane of individual graphene layers [50].

Lapuerta et al. [50] used a Raman analysis for the characterization of different types of soot retrieved from a DPF. They found that soot produced from Biodiesel combustion show graphite-like structure with a low amorphous carbon concentration, which is in contradiction with the reactivity observed for Biodiesel soot. They attributed this high reactivity to high 
curvatures of carbon fringe present in the structure of the particles of Biodiesel soot, which enhance the carbon sheets to detach and form smaller carbon segments with a higher specific surface area.

The different fitted spectra of soot samples (Figure 7) indicate a very similar structure, although MD30 soot may show a slightly higher intensity of the D-peak indicating a slightly higher ordered nanostructure [51]. The intensities ratio $I_{D} / I_{G}=0.93$ for the MD30 soot is also slightly higher compared to that of MD7 soot and Aref soot, $I_{D} / I_{G}=0.89$ and $I_{D} / I_{G}=0.88$, respectively, indicating an increase of the structural order. In addition, a small shift of the Gband is more pronounced for the Aref soot $\left(1591 \mathrm{~cm}^{-1}\right)$ compared to MD7 soot and MD30 soot both at $1589 \mathrm{~cm}^{-1}$, assuming that the graphite sheets in the Aref soot structure are slightly smaller and less organized. Overall, Aref soot generated from the combustion of the Diesel surrogate seem to show less ordered graphite-like structures and higher amorphous carbon concentration than the Biodiesel-derived MD7 soot and MD30 soot. This is in good agreement with the observations of previous works [26,27].

\subsection{Soot oxidative reactivity analysis by TPOs}

The soot reactivity has been determined by temperature-programmed oxidation experiments under different oxidizing environments (Figure 8 to Figure 11). The temperature of maximal emission $T_{\max }$ is a measure of the soot oxidation reactivity [52].

For each carbon sample, the activity order of the gas mixture $\left(\mathrm{O}_{2}<\mathrm{NO}_{2}<\mathrm{NO}_{2}+\mathrm{O}_{2}<\right.$ $\mathrm{NO}_{2}+\mathrm{O}_{2}+\mathrm{H}_{2} \mathrm{O}$ ) is found like in previous works [53-55]. In presence of only $\mathrm{O}_{2}$, the soot ignition starts after $500{ }^{\circ} \mathrm{C}$ (Figure 8), while under $\mathrm{NO}_{2}$ the ignition occurs before $200{ }^{\circ} \mathrm{C}$ (Figure 9). The catalytic activity of water at low temperatures is clear (Figure 10 and Figure 11): Aref soot achieved, at $300{ }^{\circ} \mathrm{C}$ for example, a carbon specific oxidation rate three times greater with water than under $\mathrm{NO}_{2}+\mathrm{O}_{2}$. 
In presence of only oxygen, burner Biodiesel soot emit mostly $\mathrm{CO}$, in contrary to Diesel soot, suggesting a different oxidation behavior, see Figure 12 . With $\mathrm{NO}_{2}$ in the gas mixture, a better oxidation is allowed and Aref soot, MD7 soot, MD30 soot and B7-BM-CA soot here present similar $\mathrm{CO} / \mathrm{CO}_{2}$ emissions, hence a closer behavior (Figure 13).

Under $\mathrm{NO}_{2}$ (Figure 9Erreur ! Source du renvoi introuvable.) the complete oxidation of the soot bed is not obtained at the end of the experiment $\left(700^{\circ} \mathrm{C}\right)$.

Under $\mathrm{NO}_{2}+\mathrm{O}_{2}+\mathrm{H}_{2} \mathrm{O}$ (Figure 11), a new shape of TPO profiles is obtained: several peaks can be observed. The presence of these peaks can be attributed to the existence of different types of carbon sites. The peak around $500{ }^{\circ} \mathrm{C}$ is linked to the oxidation of the most reactive carbon sites corresponding to the most amorphous carbon site (D-band of the Raman spectrum as observed in Figure 6 and Figure 7). The last peak (around $600{ }^{\circ} \mathrm{C}$ ) matches with the less reactive carbon sites corresponding to more graphitic carbon sites (G-band of the Raman spectrum observed in Figure 6 and Figure 7).

During TPO experiments, whatever the conditions, the four soot samples present the same reactivity order: Aref soot $>$ MD7 soot $>$ B7-BM-CA soot $>$ MD30 soot (Figure 8 to Figure 11). Whatever the MD concentration, surrogate soot present the same reactivity order than Biodiesel soot. Even if the addition of oxygenated compounds does not lead to more reactive soot as expected, a direct correlation exists between MD concentration and burner soot reactivity.

Several hypotheses are proposed to explain this activity hierarchy. First, the reactivity of burner soot is linked to their oxygen content: the higher $\mathrm{O}$ percentage, the higher soot reactivity $[19,56,57]$. Second, the better reactivity of the Aref soot can be linked to its higher SOF content, as it can initiate carbon oxidation [58]. Moreover, the shoulder visible around $200{ }^{\circ} \mathrm{C}$ on all Aref soot TPO profiles is attributed to the oxidation of volatiles compounds. Soot with heavy HAP condensed at the surface, hence with high SOF content, will also have a 
more amorphous structure. This type of structure allows a better access to oxidant to carbon material and therefore soot will be more active $[28,48,59,60]$. The Raman spectroscopy pointed out the greater disorder of the Aref soot carbon structure (see section 3.4).

Moreover, the reference surrogate Aref contains 30\% of $\alpha$-methylnaphthalene. A greater aromatic content will enhance soot reactivity. A dilution effect occurs when adding MD to Aref, resulting in a replacement of highly sooting components which are known as promotors for the soot formation $(\alpha-\mathrm{MN})$ with less sootier components like paraffinic chains, whatever the oxygen concentration contained in the MD.

Finally, the addition of oxygenated compounds in the Aref mixture modifies the characteristics of the surrogate. This chemical effect leads to the production by fuel pyrolysis of oxygenated species and radical species like $\mathrm{O}$ and $\mathrm{OH}$, which enhance the soot oxidation and affect the soot reactivity.

\section{Conclusion}

This study focused on the impacts of oxygenated compounds concentration on both sooting tendencies and soot oxidative reactivity of Diesel and Biodiesel surrogates. The flames have been established under atmospheric conditions using the Santoro axisymmetric diffusion flame burner. Sooting propensities were evaluated in terms of Yield Sooting Indices (YSIs) for methane diffusion flames doped with $35,000 \mathrm{ppm}$ vapors of tested surrogate. Data concerning the soot volume fraction were extracted using the light extinction method (LEM). The soot samples have been characterized using laser granulometry, Raman spectroscopy, thermogravimetric analyses (TGA) and temperature programmed oxidation (TPO) experiments. Sooting propensities and soot characterization results are summarized in the following observations: 
- Biodiesel surrogates are proved to be effective in suppressing soot formation.

- An increase in Biodiesel content means a decrease of sooting tendencies of the tested fuels in non-premixed diffusion flames.

- A decrease in particle size distribution is noticed when adding oxygenated compounds to a Diesel surrogate.

- Soot generated from the combustion of Diesel surrogates seem to show less ordered graphite-like structures and higher amorphous carbon concentration than the Biodiesel-derived soot.

- The oxidative reactivity of soot generated from the diffusion flame burner decreases when increasing the Biodiesel percentage.

The results presented here prove that the addition of oxygenate compounds to a Diesel surrogate fuel reduces the tendency of soot particles production. However, Biodiesel-derived soot particles are smaller and less reactive than Diesel-derived soot and require specific oxidation conditions and higher temperatures in order to be eliminated.

To conclude, adding oxygenate compounds to a Diesel surrogate burning in a laminar co-flow diffusion flame burner has the same impact on sooting propensities (i.e. decrease in soot formation) like when the combustion is carried out in a Diesel engine. Moreover, it can be noticed analyzing the results obtained from laser granulometry and TPOs that the particle size distribution and the oxidative reactivity of model soot collected from the burner are in the same range of size and oxidation temperature as soot derived from a Diesel engine working under specific conditions and with different types of fuel blending (B7-BM-CA). Soot derived from burner installation can thus be considered as a suitable model for further studies of Biodiesel impact on soot emissions and reactivity.

Additional works will be realized in order to highlight the effect of carbon chain length of the oxygenate additives as well as the increase of pressure on both soot formation and reactivity. 


\section{References}

1. Escobar, J. C.; Lora, E. S.; Venturini, O. J.; Yáñez, E. E.; Castillo, E. F.; Almazan, O. Biofuels: Environment, technology and food security. Renew. Sustain. Energy Rev. 2009, 13, 1275-1287.

2. Schuchardt, U.; Sercheli, R.; Vargas, R. M. Transesterification of vegetable oils: a review. J. Braz. Chem. Soc. 1998, 9, 199-210.

3. Agarwal, A. K. Biofuels (alcohols and biodiesel) applications as fuels for internal combustion engines. Prog. Energy Combust. Sci. 2007, 33, 233-271.

4. Armas, O.; Yehliu, K.; Boehman, A. L. Effect of alternative fuels on exhaust emissions during diesel engine operation with matched combustion phasing. Fuel 2010, 89, 438456.

5. Lapuerta, M.; Armas, 0.; Rodriguezfernandez, J. Effect of biodiesel fuels on diesel engine emissions. Prog. Energy Combust. Sci. 2008, 34, 198-223.

6. Szybist, J. P.; Song, J.; Alam, M.; Boehman, A. L. Biodiesel combustion, emissions and emission control. Fuel Process. Technol. 2007, 88, 679-691.

7. McCormick, R. L.; Graboski, M. S.; Alleman, T. L.; Herring, A. M.; Tyson, K. S. Impact of Biodiesel Source Material and Chemical Structure on Emissions of Criteria Pollutants from a Heavy-Duty Engine. Environ. Sci. Technol. 2001, 35, 1742-1747.

8. Pickett, L. M.; Siebers, D. L. Soot in diesel fuel jets: effects of ambient temperature, ambient density, and injection pressure. Combust. Flame 2004, 138, 114-135.

9. Harrison, R. M.; Yin, J. Particulate matter in the atmosphere: which particle properties are important for its effects on health? Sci. Total Environ. 2000, 249, 85-101.

10. Valavanidis, A.; Fiotakis, K.; Vlahogianni, T.; Bakeas, E. B.; Triantafillaki, S.;

Paraskevopoulou, V.; Dassenakis, M. Characterization of atmospheric particulates, particle-bound transition metals and polycyclic aromatic hydrocarbons of urban air in the centre of Athens (Greece). Chemosphere 2006, 65, 760-768.

11. Vedal, S. Ambient Particles and Health: Lines that Divide. J. Air Waste Manag. Assoc. $1997,47,551-581$.

12. Soots (IARC Summary \& Evaluation, Supplement7, 1987)

http://www.inchem.org/documents/iarc/suppl7/soots.html (accessed May 23, 2016). 
13. Minchin, S. T. Luminous stationary flames: the quantitative relationship between flame dimensions at the sooting point and chemical composition, with special reference to petroleum hydrocarbons. J. Inst. Pet. Technol. 1931, 17, 102-120.

14. Clarke, A. E.; Hunter, T. G.; Garner, F. H. The tendency to smoke of organic substances on burning. Part I. J. Inst. Pet. 1946, 32, 627-642.

15. Schalla, R. L.; McDonald, G. E. Variation in smoking tendency. Ind. Eng. Chem. 1953, 45, 1497-1500.

16. Pepiotdesjardins, P.; Pitsch, H.; Malhotra, R.; Kirby, S.; Boehman, A. Structural group analysis for soot reduction tendency of oxygenated fuels. Combust. Flame 2008, 154, 191-205.

17. Lemaire, R.; Lapalme, D.; Seers, P. Analysis of the sooting propensity of C-4 and C-5 oxygenates: Comparison of sooting indexes issued from laser-based experiments and group additivity approaches. Combust. Flame 2015, 162, 3140-3155.

18. Dmitriev, A. M.; Knyazkov, D. A.; Bolshova, T. A.; Shmakov, A. G.; Korobeinichev, O. P. The effect of methyl pentanoate addition on the structure of premixed fuel-rich nheptane/toluene flame at atmospheric pressure. Combust. Flame 2015, 162, 1964-1975. 19. Seong, H. J.; Boehman, A. L. Studies of soot oxidative reactivity using a diffusion flame burner. Combust. Flame 2012, 159, 1864-1875.

20. McEnally, C. S.; Pfefferle, L. D. Sooting Tendencies of Oxygenated Hydrocarbons in Laboratory-Scale Flames. Environ. Sci. Technol. 2011, 45, 2498-2503.

21. Boehman, A. L.; Song, J.; Alam, M. Impact of Biodiesel Blending on Diesel Soot and the Regeneration of Particulate Filters. Energy Fuels 2005, 19, 1857-1864.

22. Vander Wal, R. L.; Bryg, V. M.; Hays, M. D. Fingerprinting soot (towards source identification): Physical structure and chemical composition. J. Aerosol Sci. 2010, 41, 108-117.

23. Vander Wal, R. L.; Tomasek, A. J. Soot oxidation. Combust. Flame 2003, 134, 1-9. 24. Ghiassi, H.; Toth, P.; Lighty, J. S. Sooting behaviors of n-butanol and n-dodecane blends. Combust. Flame 2014, 161, 671-679.

25. Barrientos, E.; Maricq, M.; Boehman, A.; Anderson, J. Impact of Ester Structures on the Soot Characteristics and Soot Oxidative Reactivity of Biodiesel. SAE Tech. Pap. 2015. 26. Song, J.; Alam, M.; Boehman, A.; Kim, U. Examination of the oxidation behavior of biodiesel soot. Combust. Flame 2006, 146, 589-604. 
27. Song, J.; Alam, M.; Boehman, A. L. Impact of alternative fuels on soot properties and DPF regeneration. Combust. Sci. Technol. 2007, 179, 1991-2037.

28. Löpez Suárez, F.-E.; Bueno-López, A.; Illán-Gómez, M.-J.; Ura, B.; Trawczynski, J. Study of the uncatalyzed and catalyzed combustion of diesel and biodiesel soot. Catal. Today 2011, 176, 182-186.

29. Santoro, R. J.; Semerjian, H. G.; Dobbins, R. A. Soot particle measurements in diffusion flames. Combust. Flame 1983, 51, 203-218.

30. Mcenally, C.; Pfefferle, L. Improved sooting tendency measurements for aromatic hydrocarbons and their implications for naphthalene formation pathways. Combust. Flame 2007, 148, 210-222.

31. Kashif, M.; Guibert, P.; Bonnety, J.; Legros, G. Sooting tendencies of primary reference fuels in atmospheric laminar diffusion flames burning into vitiated air. Combust. Flame 2014, 161, 1575-1586.

32. Farrell, J. T.; Cernansky, N. P.; Dryer, F. L.; Friend, D. G.; Hergart, C. A.; Law, C. K.; McDavid, R. M.; Mueller, C. J.; Patel, A. K.; Pitsch, H. Development of an experimental database and kinetic models for surrogate diesel fuels. SAE Tech. Pap. 2007, 0201. 33. Lemaire, R.; Faccinetto, A.; Therssen, E.; Ziskind, M.; Focsa, C.; Desgroux, P. Experimental comparison of soot formation in turbulent flames of Diesel and surrogate Diesel fuels. Proc. Combust. Inst. 2009, 32, 737-744.

34. Ramirez L., H. P.; Hadj-Ali, K.; Diévart, P.; Moréac, G.; Dagaut, P. Kinetics of Oxidation of Commercial and Surrogate Diesel Fuels in a Jet-Stirred Reactor: Experimental and Modeling Studies. Energy Fuels 2010, 24, 1668-1676.

35. Ramirez, H. P.; Hadj-Ali, K.; Diévart, P.; Dayma, G.; Togbé, C.; Moréac, G.; Dagaut, P. Oxidation of commercial and surrogate bio-Diesel fuels (B30) in a jet-stirred reactor at elevated pressure: Experimental and modeling kinetic study. Proc. Combust. Inst. 2011, $33,375-382$.

36. Kashif, M.; Bonnety, J.; Guibert, P.; Morin, C.; Legros, G. Soot volume fraction fields in unsteady axis-symmetric flames by continuous laser extinction technique. Opt. Express 2012, 20, 28742-28751.

37. Legros, G.; Gomez, T.; Fessard, M.; Gouache, T.; Ader, T.; Guibert, P.; Sagaut, P.; Torero, J. L. Magnetically induced flame flickering. Proc. Combust. Inst. 2011, 33, 10951103. 
38. Daun, K. J.; Thomson, K. A.; Liu, F.; Smallwood, G. J. Deconvolution of axisymmetric flame properties using Tikhonov regularization. Appl. Opt. 2006, 45, 4638-4646.

39. AAkesson, E. O.; Daun, K. J. Parameter selection methods for axisymmetric flame tomography through Tikhonov regularization. Appl. Opt. 2008, 47, 407-416.

40. Arana, C. P.; Pontoni, M.; Sen, S.; Puri, I. K. Field measurements of soot volume fractions in laminar partially premixed coflow ethylene/air flames. Combust. Flame $2004,138,362-372$.

41. Tran, M. K.; Dunn-Rankin, D.; Pham, T. K. Characterizing sooting propensity in biofuel-diesel flames. Combust. Flame 2012, 159, 2181-2191.

42. Lin, K. C.; Lai, J. Y. W.; Violi, A. The role of the methyl ester moiety in biodiesel combustion: A kinetic modeling comparison of methyl butanoate and n-butane. Fuel $2012,92,16-26$.

43. Kang, K. T.; Hwang, J. Y.; Chung, S. H.; Lee, W. Soot zone structure and sooting limit in diffusion flames : comparaison of counterflow andco-flow flames. Combust. Flame 1997, 109, 266-281.

44. Sadezky, A.; Muckenhuber, H.; Grothe, H.; Niessner, R.; Pöschl, U. Raman microspectroscopy of soot and related carbonaceous materials: Spectral analysis and structural information. Carbon 2005, 43, 1731-1742.

45. Lamharess, N. Etude de la réactivité des suies issues de la combustion des biocarburants : interaction avec le filtre à particules catalysé, Université Pierre et Marie Curie - Paris VI, 2012.

46. Knauer, M.; Schuster, M. E.; Su, D.; Schlögl, R.; Niessner, R.; Ivleva, N. P. Soot Structure and Reactivity Analysis by Raman Microspectroscopy, Temperature-Programmed Oxidation, and High-Resolution Transmission Electron Microscopy. J. Phys. Chem. A $2009,113,13871-13880$.

47. Knauer, M.; Carrara, M.; Rothe, D.; Niessner, R.; Ivleva, N. P. Changes in Structure and Reactivity of Soot during Oxidation and Gasification by Oxygen, Studied by Micro-Raman Spectroscopy and Temperature Programmed Oxidation. Aerosol Sci. Technol. 2009, 43, $1-8$.

48. Ivleva, N. P.; McKeon, U.; Niessner, R.; Pöschl, U. Raman Microspectroscopic Analysis of Size-Resolved Atmospheric Aerosol Particle Samples Collected with an ELPI: Soot, Humic-Like Substances, and Inorganic Compounds. Aerosol Sci. Technol. 2007, 41, 655671. 
49. Ferrari, A. C.; Robertson, J. Interpretation of Raman spectra of disordered and amorphous carbon. Phys. Rev. B 2000, 61, 14095.

50. Lapuerta, M.; Oliva, F.; Agudelo, J. R.; Boehman, A. L. Effect of fuel on the soot nanostructure and consequences on loading and regeneration of diesel particulate filters. Combust. Flame 2012, 159, 844-853.

51. Ess, M. N.; Bladt, H.; Mühlbauer, W.; Seher, S. I.; Zöllner, C.; Lorenz, S.; Brüggemann, D.; Nieken, U.; Ivleva, N. P.; Niessner, R. Reactivity and structure of soot generated at varying biofuel content and engine operating parameters. Combust. Flame 2016, 163, 157-169.

52. Schmid, J.; Grob, B.; Niessner, R.; Ivleva, N. P. Multiwavelength Raman Microspectroscopy for Rapid Prediction of Soot Oxidation Reactivity. Anal. Chem. 2011, 83, 1173-1179.

53. Jacquot, F.; Logie, V.; Brilhac, J. F.; Gilot, P. Kinetics of the oxidation of carbon black by NO2: Influence of the presence of water and oxygen. Carbon 2002, 40, 335-343.

54. Zouaoui, N.; Labaki, M.; Jeguirim, M. Diesel soot oxidation by nitrogen dioxide, oxygen and water under engine exhaust conditions: Kinetics data related to the reaction mechanism. Comptes Rendus Chim. 2014, 17, 672-680.

55. Jeguirim, M. Contribution à la compréhension du mécanisme d'oxydation des suies par la dioxyde d'azote dans les conditions d'échappement diesel - Influence de la présence d'un catalyseur à base de platine, Mulhouse, 2005.

56. Song, J.; Alam, M.; Boehman, A. L. Impact of alternative fuels on soot properties and DPF regeneration. Combust. Sci. Technol. 2007, 179, 1991-2037.

57. Löpez Suárez, F.-E.; Bueno-López, A.; Illán-Gómez, M.-J.; Ura, B.; Trawczynski, J. Study of the uncatalyzed and catalyzed combustion of diesel and biodiesel soot. Catal. Today $2011,176,182-186$.

58. Setiabudi, A.; Makkee, M.; Moulijn, J. A. The role of NO2 and 02 in the accelerated combustion of soot in diesel exhaust gases. Appl. Catal. B Environ. 2004, 50, 185-194. 59. Song, J.; Alam, M.; Boehman, A. L.; Miller, K. Characterization of diesel and biodiesel soot. Prepr Pap-Am Chem Soc Div Fuel Chem 2004, 49, 767-769.

60. Yehliu, K.; Vander Wal, R. L.; Armas, O.; Boehman, A. L. Impact of fuel formulation on the nanostructure and reactivity of diesel soot. Combust. Flame 2012, 159, 3597-3606. 
Table 1 : Composition of the Diesel and Biodiesel surrogates

\begin{tabular}{|c|c|c|}
\hline \multirow{2}{*}{ Surrogate } & Composition (\% Molar) & $\begin{array}{c}\text { Percentage of } \\
\text { additives } \\
\text { (\% molar) }\end{array}$ \\
\hline Aref & $70 \%$ n-decane $+30 \%$ o-methylnaphthalene & ---------- \\
\hline MD3 & Aref + methyldecanoate & 3 \\
\hline MD7 & Aref + methyldecanoate & 7 \\
\hline MD15 & Aref + methyldecanoate & 15 \\
\hline MD30 & Aref + methyldecanoate & 30 \\
\hline
\end{tabular}


Table 2 : Experimental parameters kept constant for the evaluation of YSIs.

\begin{tabular}{cc} 
Parameter & \\
\hline Ambient pressure $(\mathbf{a t m})$ & 1.0 \\
Ambient temperature $\left({ }^{\circ} \mathbf{C}\right)$ & 20 \\
Carrier gas composition & $\mathrm{CH}_{4}(100 \%)$ \\
Carrier gas flow rate $\left(\mathbf{c m}^{\mathbf{3}} / \mathbf{m i n}\right)$ & $210 \pm 1.2$ \\
Co-flowing air flow rate $\left(\mathbf{c m}^{\mathbf{3}} / \mathbf{m i n}\right)$ & $60000 \pm 360$ \\
Evaporator temperature $\left({ }^{\circ} \mathbf{C}\right)$ & $150 \pm 1$ \\
Heated lines temperature $\left({ }^{\circ} \mathbf{C}\right)$ & $180 \pm 1$ \\
Reference YSIs & YSI (n-heptane) $=0$ \\
& YSI (isooctane) $=48.6$ \\
\hline
\end{tabular}


Table 3: TPOs experimental conditions

\begin{tabular}{|c|c|c|c|c|}
\hline \multirow{2}{*}{ Gas mixture } & Gas composition & $\begin{array}{c}\text { Flow } \\
(\mathrm{Nl} / \mathrm{h})\end{array}$ & $\begin{array}{c}\text { Soot mass } \\
(\mathrm{mg})\end{array}$ & $\begin{array}{c}\text { Heating ramp } \\
\left({ }^{\circ} \mathrm{C} / \mathrm{min}\right)\end{array}$ \\
\hline $\mathrm{O}_{2}$ & $9 \%$ b.v. $\mathrm{O}_{2}$ in $\mathrm{Ar}$ & 15 & 5 & 10 \\
\hline $\mathrm{NO}_{2}$ & 400 ppmv $\mathrm{NO}_{2}$ in $\mathrm{N}_{2}$ & 90 & 15 & 5 \\
\hline $\mathrm{NO}_{2}+\mathrm{O}_{2}$ & 400 ppmv $\mathrm{NO}_{2}+10 \%$ b.v. $\mathrm{O}_{2}$ in $\mathrm{N}_{2}$ & 90 & 15 & 5 \\
\hline $\mathrm{NO}_{2}+\mathrm{O}_{2}+\mathrm{H}_{2} \mathrm{O}$ & 400 ppmv NO$+10 \%$ b.v. $\mathrm{O}_{2}$ & 90 & 15 & 5 \\
& $+4 \%$ b.v. $\mathrm{H}_{2} \mathrm{O}$ in $\mathrm{N}_{2}$ & & \\
\hline
\end{tabular}


Table 4 : Composition of the different soot samples

\begin{tabular}{|c|c|c|c|c|c|c|c|c|}
\hline Sample & $\mathbf{\%} \mathbf{C}^{\mathbf{1}}$ & $\mathbf{\%} \mathbf{H}^{\mathbf{1}}$ & $\mathbf{\%} \mathbf{O}^{\mathbf{1}}$ & $\mathbf{\%} \mathbf{N}^{\mathbf{1}}$ & $\mathbf{\% \mathbf { P } ^ { \mathbf { 1 } }}$ & $\mathbf{\%} \mathbf{a s h}^{\mathbf{2}}$ & $\mathbf{\%} \mathbf{H}_{2} \mathbf{O}^{\mathbf{3}}$ & $\mathbf{\%} \mathbf{S O F}^{\mathbf{4}}$ \\
\hline Aref soot & 88.51 & 0.76 & 6.02 & 0.22 & n.d. & 0.85 & 1.43 & 3.28 \\
\hline MD7 soot & 91.90 & 0.84 & 4.49 & 0.21 & n.d. & 0.91 & 0.46 & 1.82 \\
\hline MD30 soot & 93.19 & 0.70 & 2.96 & 0.20 & n.d. & 0.59 & 0.37 & 1.27 \\
\hline $\begin{array}{c}\text { B7-BM-CA } \\
\text { soot }\end{array}$ & 72.88 & 0.38 & 11.44 & 0.17 & 0.797 & 14.77 & 1.38 & 2.4 \\
\hline
\end{tabular}

${ }^{1}$ Elemental composition CHONS + ICP

${ }^{2}$ Determined from the mass loss between 20 and $700{ }^{\circ} \mathrm{C}$ in TGA under air

${ }^{3}$ Determined from the mass loss between 20 and $110^{\circ} \mathrm{C}$ in TGA under nitrogen

${ }^{4}$ Determined from the mass loss between 110 and $400{ }^{\circ} \mathrm{C}$ in TGA under nitrogen

n.d.; non-determined 


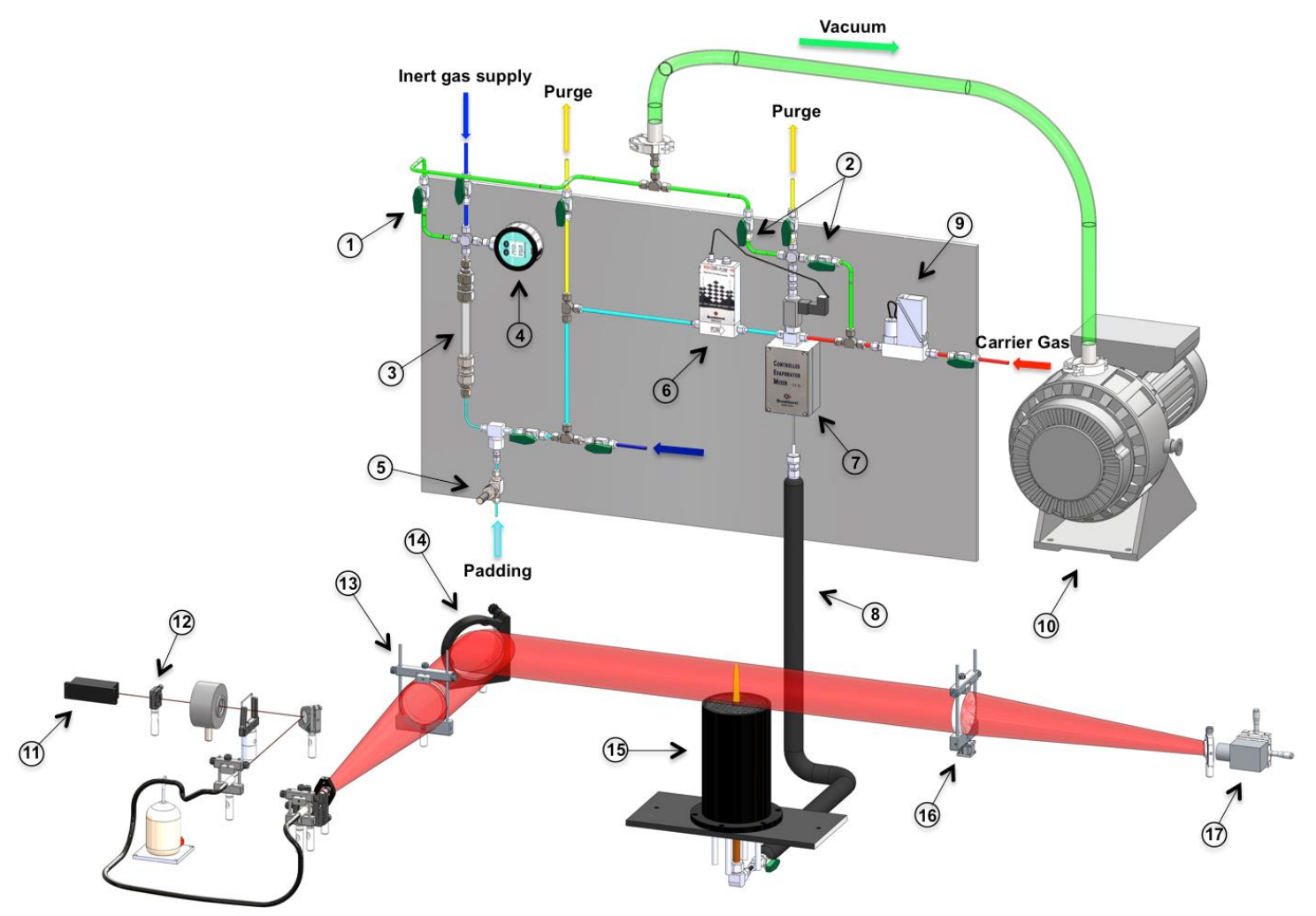

Figure 1 : Experimental setup for measuring the soot volume fraction in diffusion flames doped with methane: (1-2) valves for establishing the vacuum in the lines, (3) liquid fuel tank, (4) manometer, (5) valve to allow the padding of the liquid fuel, (6) Coriolis mass flow controller, (7) Bronkhorst controlled evaporator and mixer (CEM), (8) heated line, (9) methane flow controller, (10) vacuum pomp, (11) 100-mW continuous wave laser ( $\lambda=645 \mathrm{~nm}),(12)$ shutter, (13) collimating achromatic lens $(\mathrm{d}=75 \mathrm{~mm}, \mathrm{f}=+750 \mathrm{~mm})$, (14) mirror, (15) burner, (16) decollimating achromatic lens $(\mathrm{d}=82 \mathrm{~mm}, \mathrm{f}=+300 \mathrm{~mm})$, (17) Photon Focus MV1 12-bit progressive scan monochrome camera. 

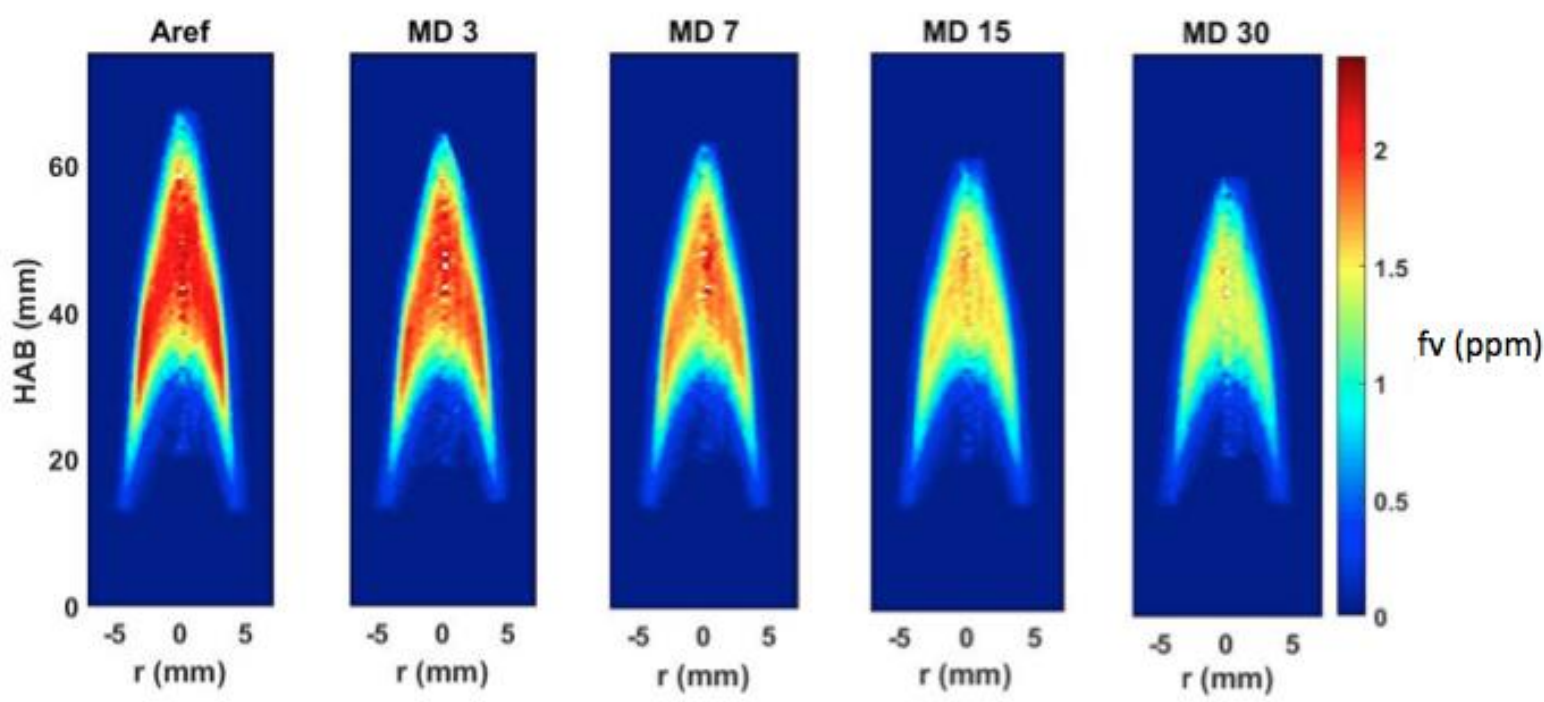

Figure 2: Soot volume fraction fields in methane diffusion flames doped with $3.5 \times 10^{-2}$ mole fraction of Diesel surrogate (Aref) and Biodiesel (MD3, MD7, MD15, MD30) vapor. 


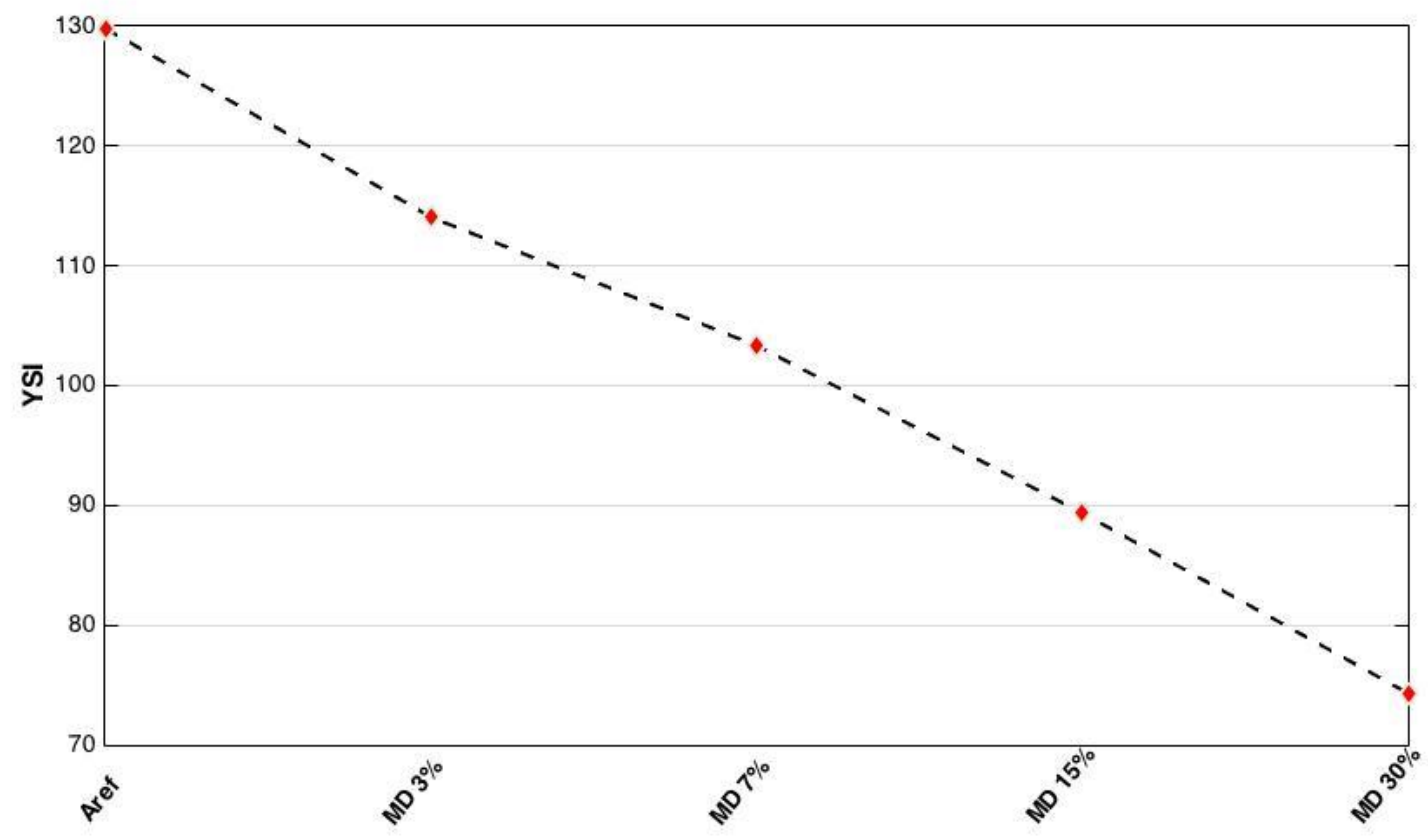

Tested Surrogates

Figure 3 : YSIs of tested Diesel and Biodiesel surrogates. The reference values 0 and 48.6 are respectively attributed to the $\mathrm{n}$-heptane and isooctane vapors.

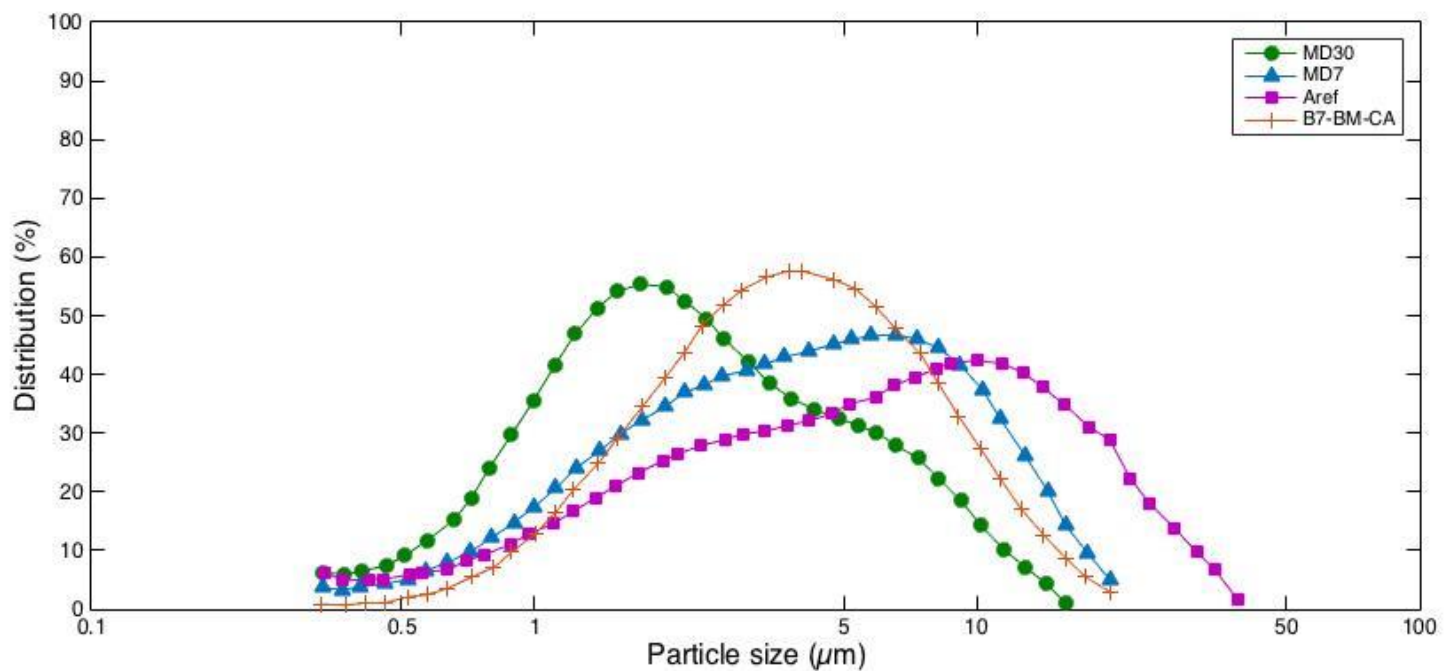

Figure 4 : Particle size distribution of four types of soot: Aref soot (purple square), MD7 soot (blue triangle), MD30 soot (green circle), B7-BM-CA soot (orange cross). 


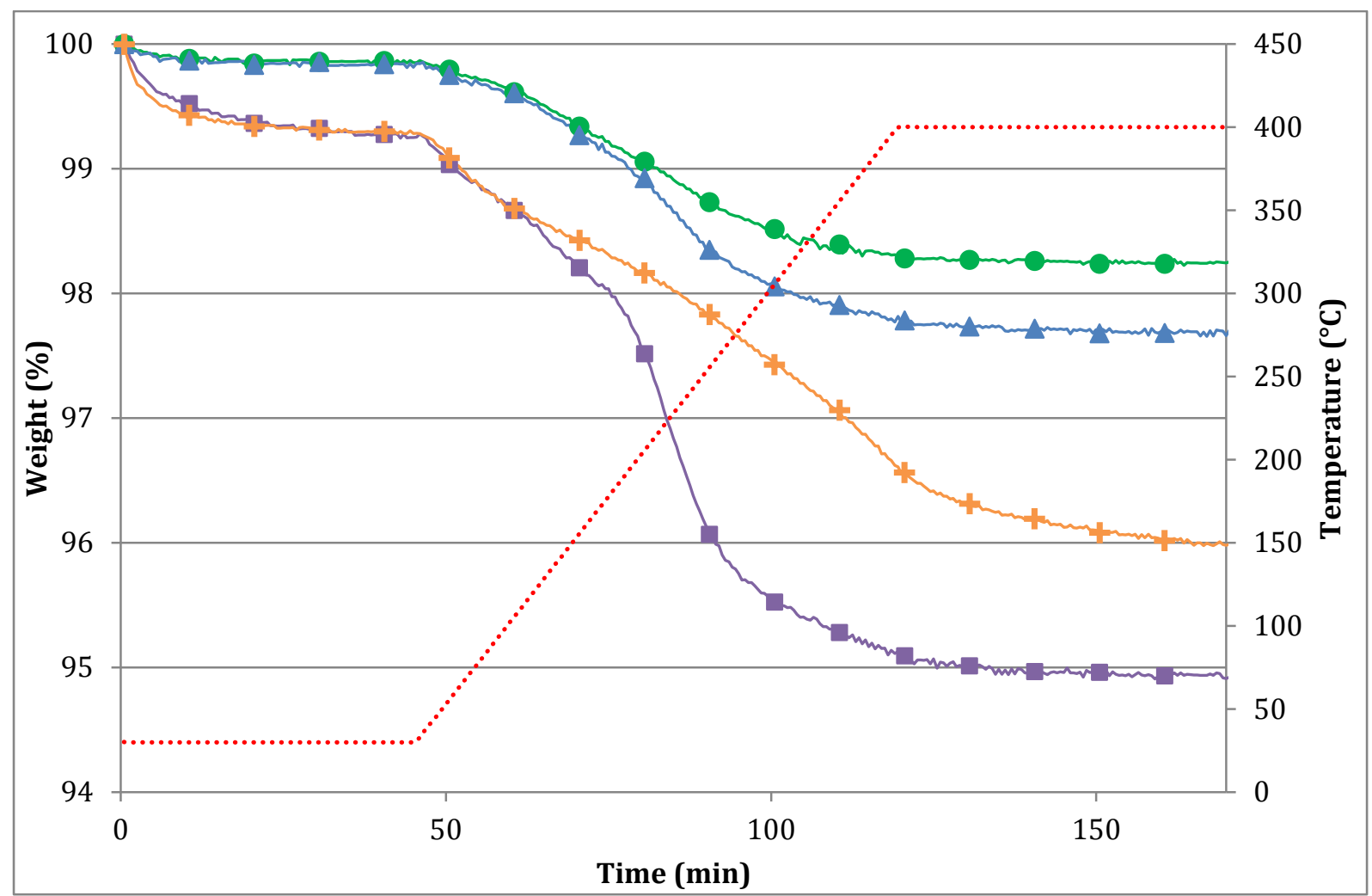

Figure 5 : TGA profiles under nitrogen of different soot: Aref soot (purple square), MD7 soot (blue triangle), MD30 soot (green circle), B7-BM-CA soot (orange cross). Temperature in red dotted line. 


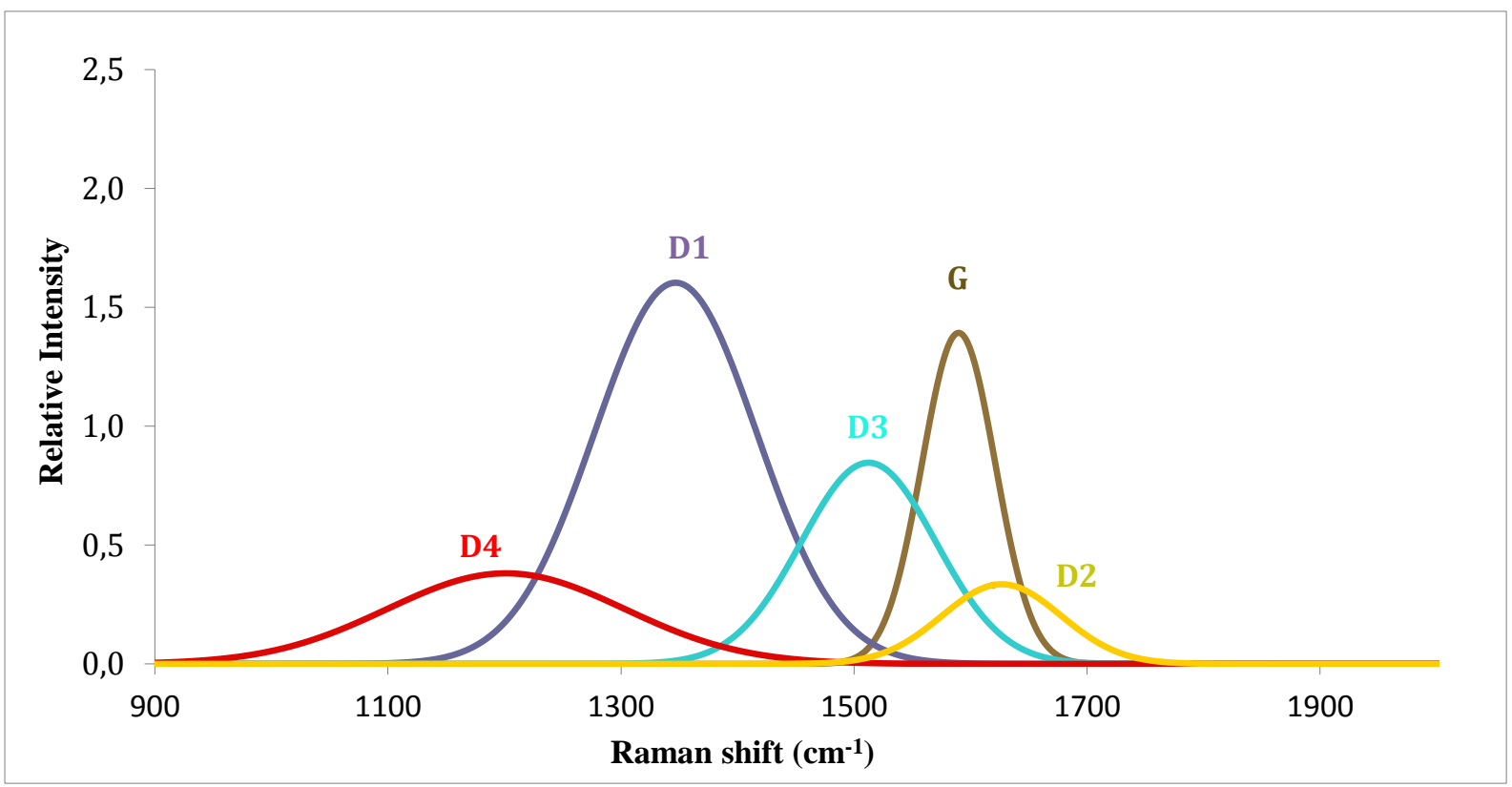

Figure 6: Analysis of the Raman spectra and curve fit of the Aref soot sample. 


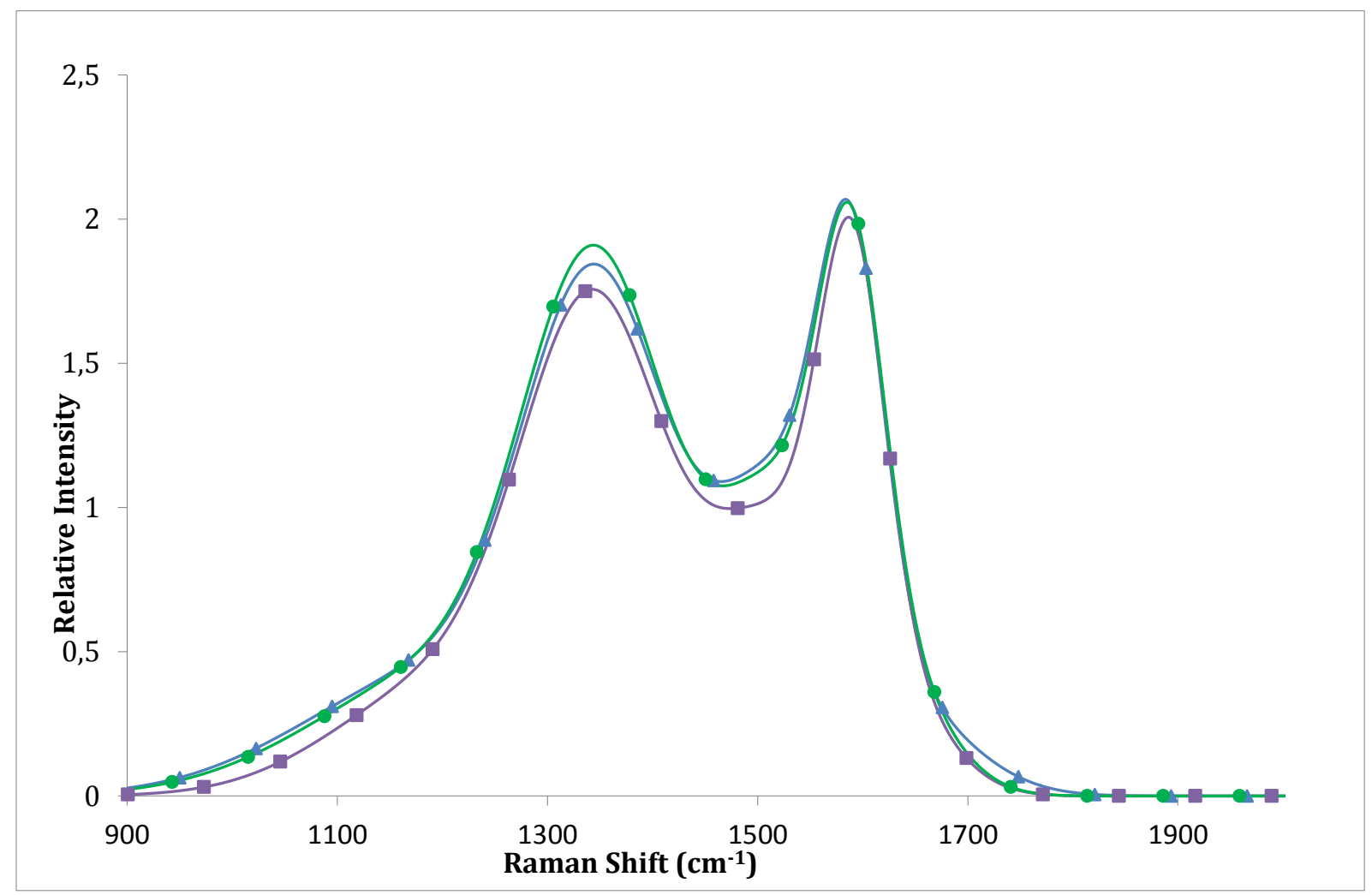

Figure 7: Raman spectrum for soot collected from the burner: Aref soot (purple square), MD7 soot (blue triangle), MD30 soot (green circle). 


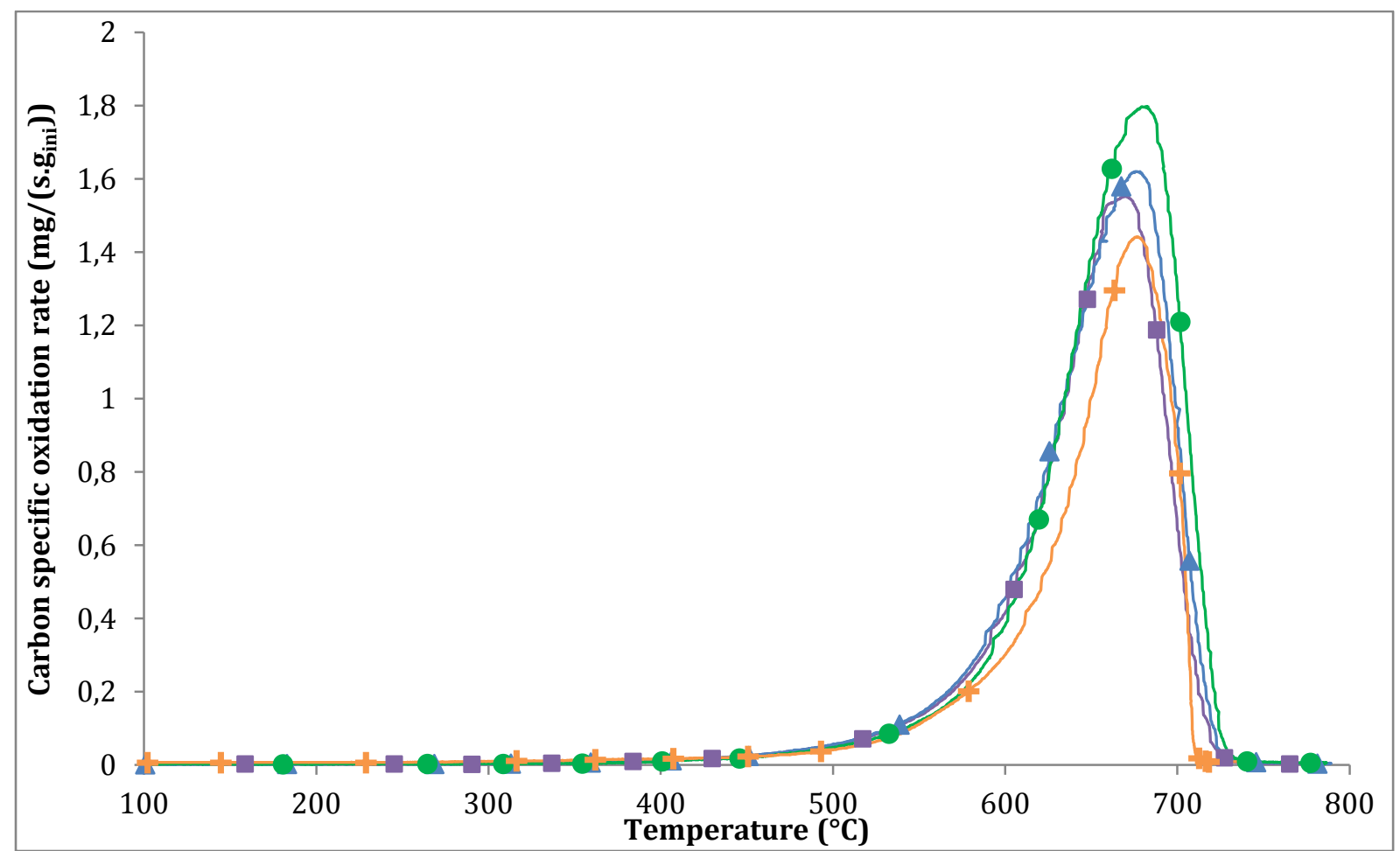

Figure 8 : TPO profiles under $\mathrm{O}_{2}(9 \%)$ of different soot: Aref soot (purple square), MD7 soot (blue triangle), MD30 soot (green circle), B7-BM-CA soot (orange cross). 


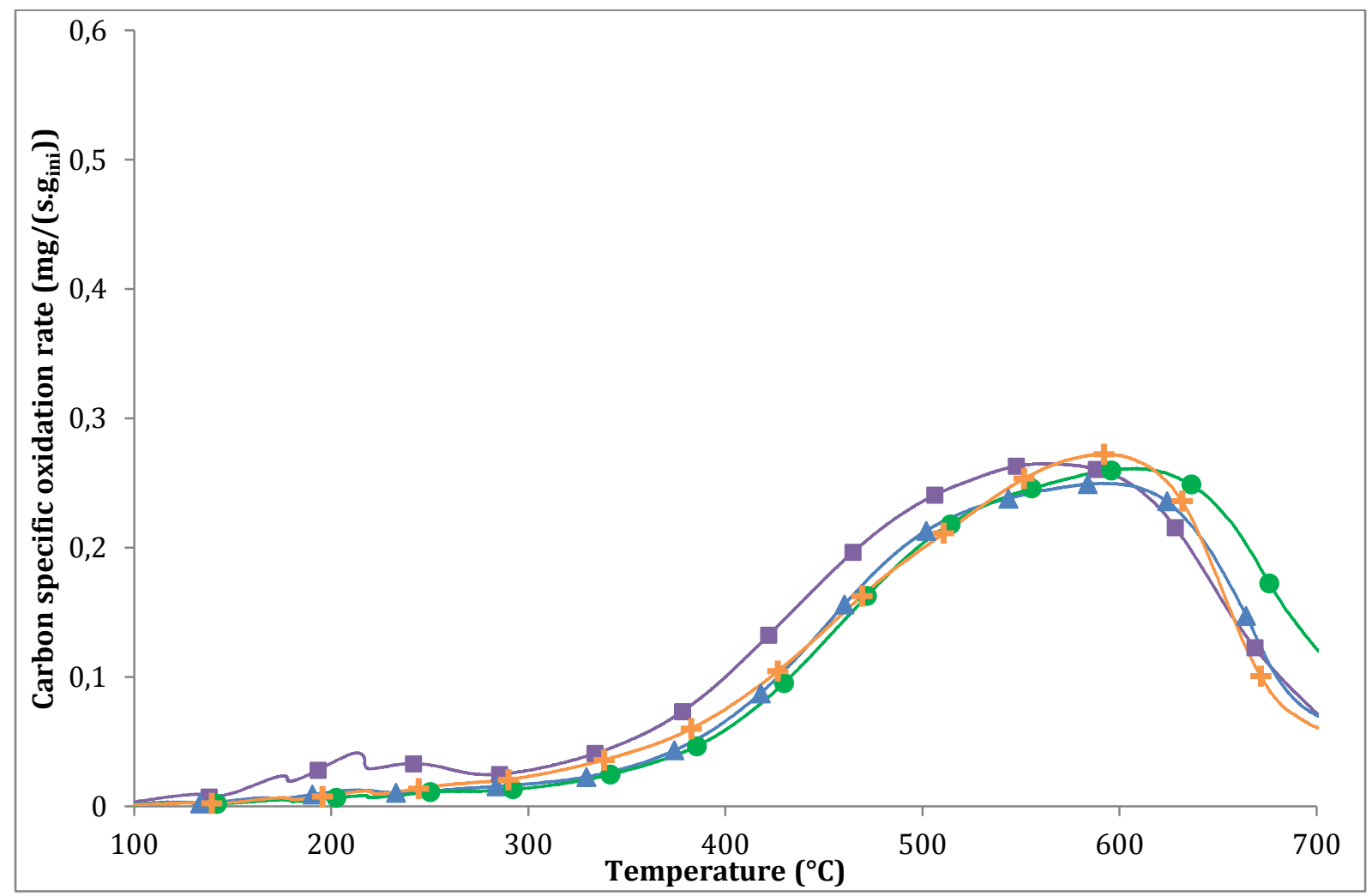

Figure 9 : TPO profiles under $\mathrm{NO}_{2}$ (400 ppm) of different soot: Aref soot (purple square), MD7 soot (blue triangle), MD30 soot (green circle), B7-BM-CA soot (orange cross). 


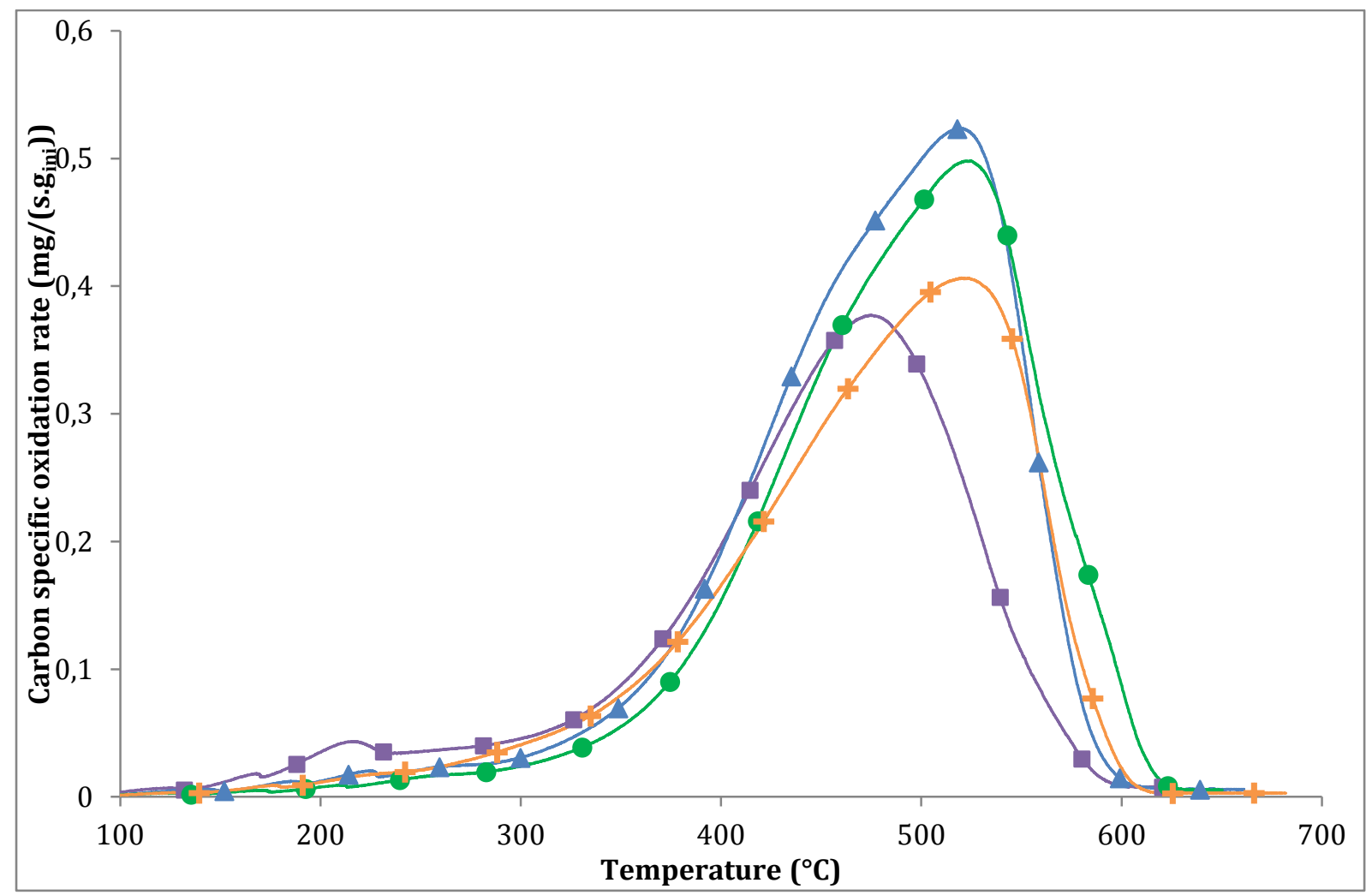

Figure 10 : TPO profiles under $\mathrm{NO}_{2}+\mathrm{O}_{2}(400 \mathrm{ppm} / 10 \%)$ of different soot: Aref soot (purple square), MD7 soot (blue triangle), MD30 soot (green circle), B7-BM-CA soot (orange cross). 


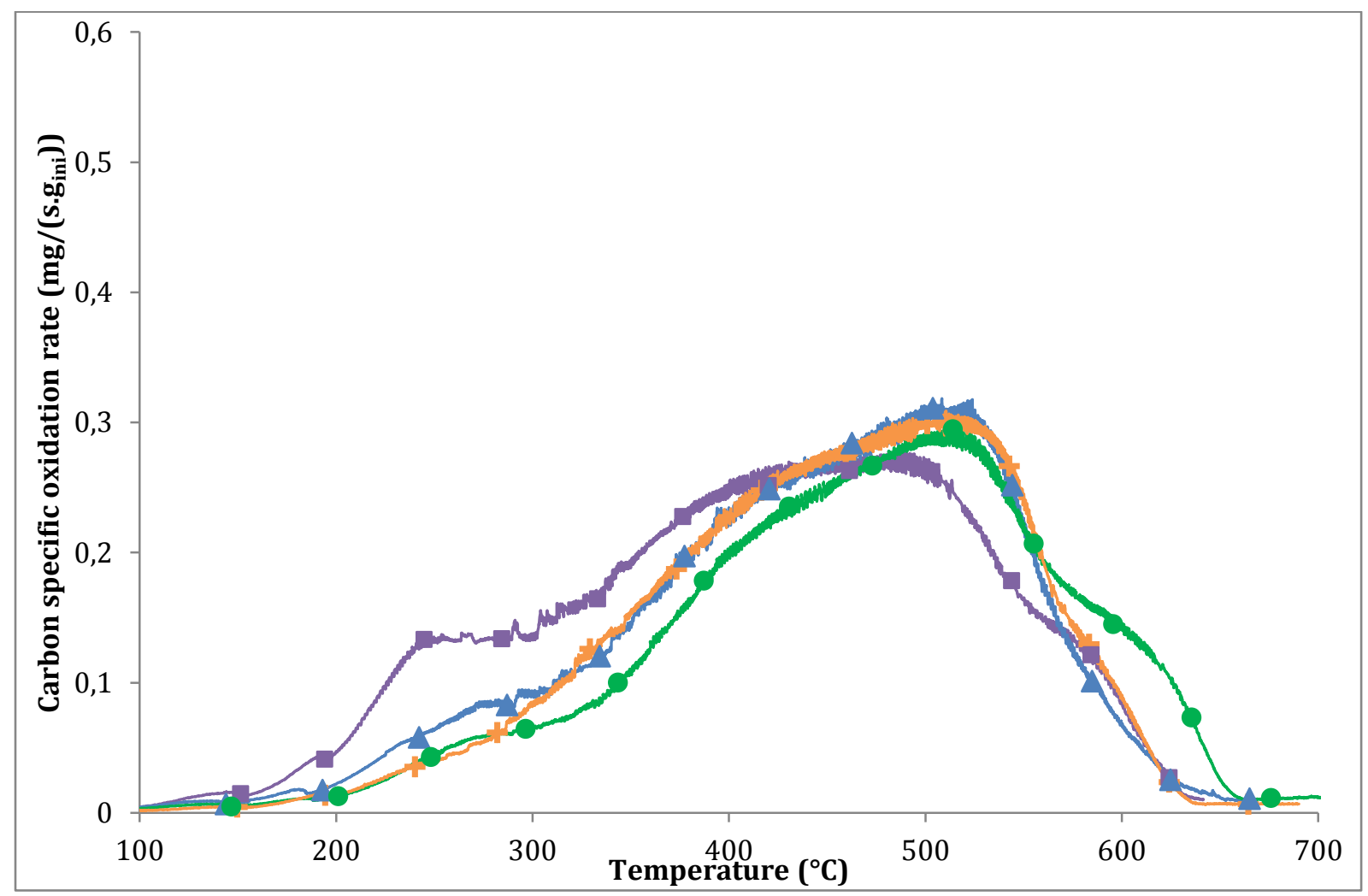

Figure 11 : TPO profiles under $\mathrm{NO}_{2}+\mathrm{O}_{2}+\mathrm{H}_{2} \mathrm{O}(400 \mathrm{ppm} / 10 \% / 4 \%)$ of different soot: Aref soot (purple square), MD7 soot (blue triangle), MD30 soot (green circle), B7-BM-CA soot (orange cross). 

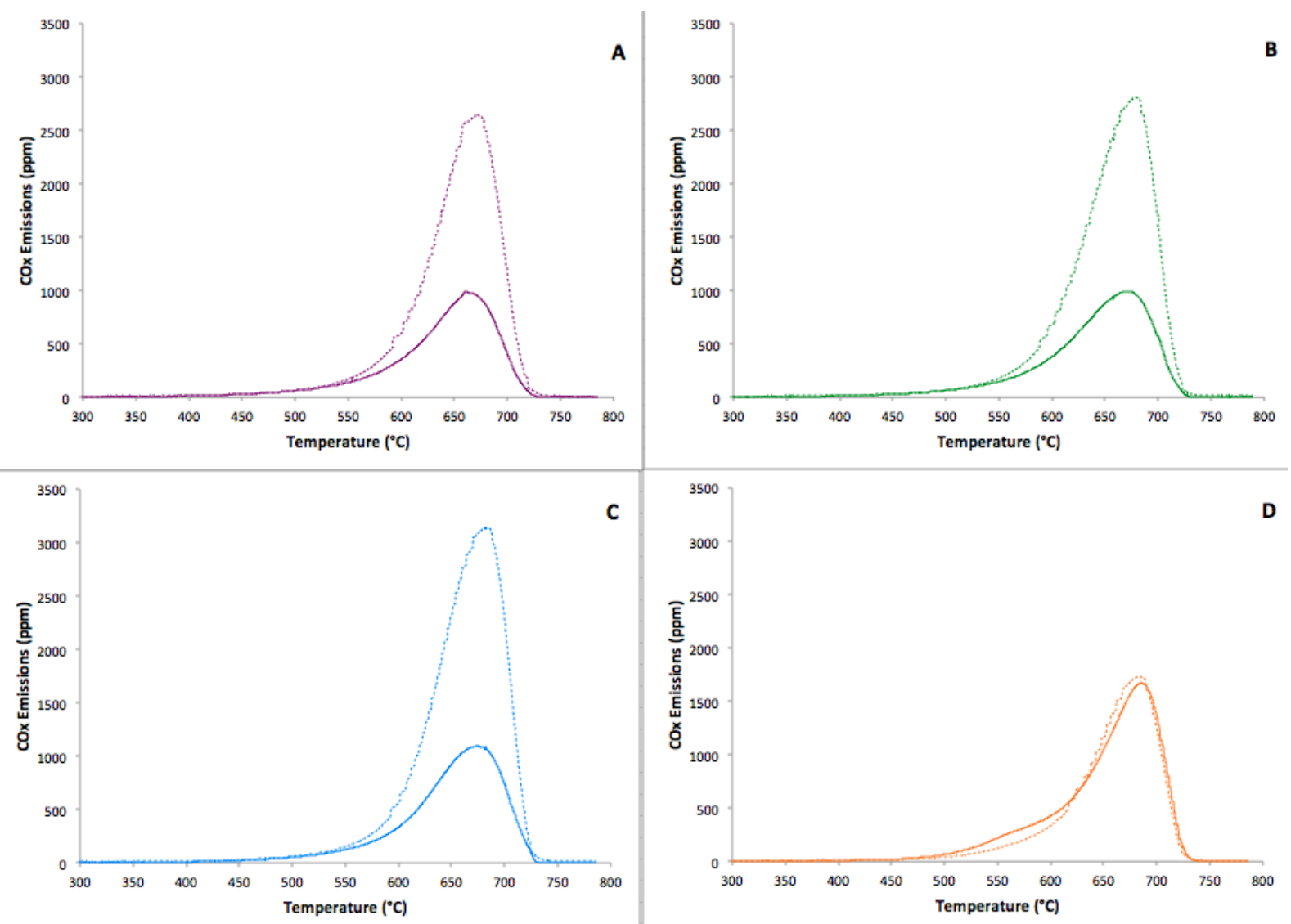

Figure 12 : $\mathrm{CO}$ (dotted line) and $\mathrm{CO}_{2}$ (full line) emissions for different soot samples under $\mathrm{O}_{2}$ : Aref soot (A -purple), MD30 soot (B - green), MD7 soot (C - blue), B7-BM-CA soot (D - orange). 

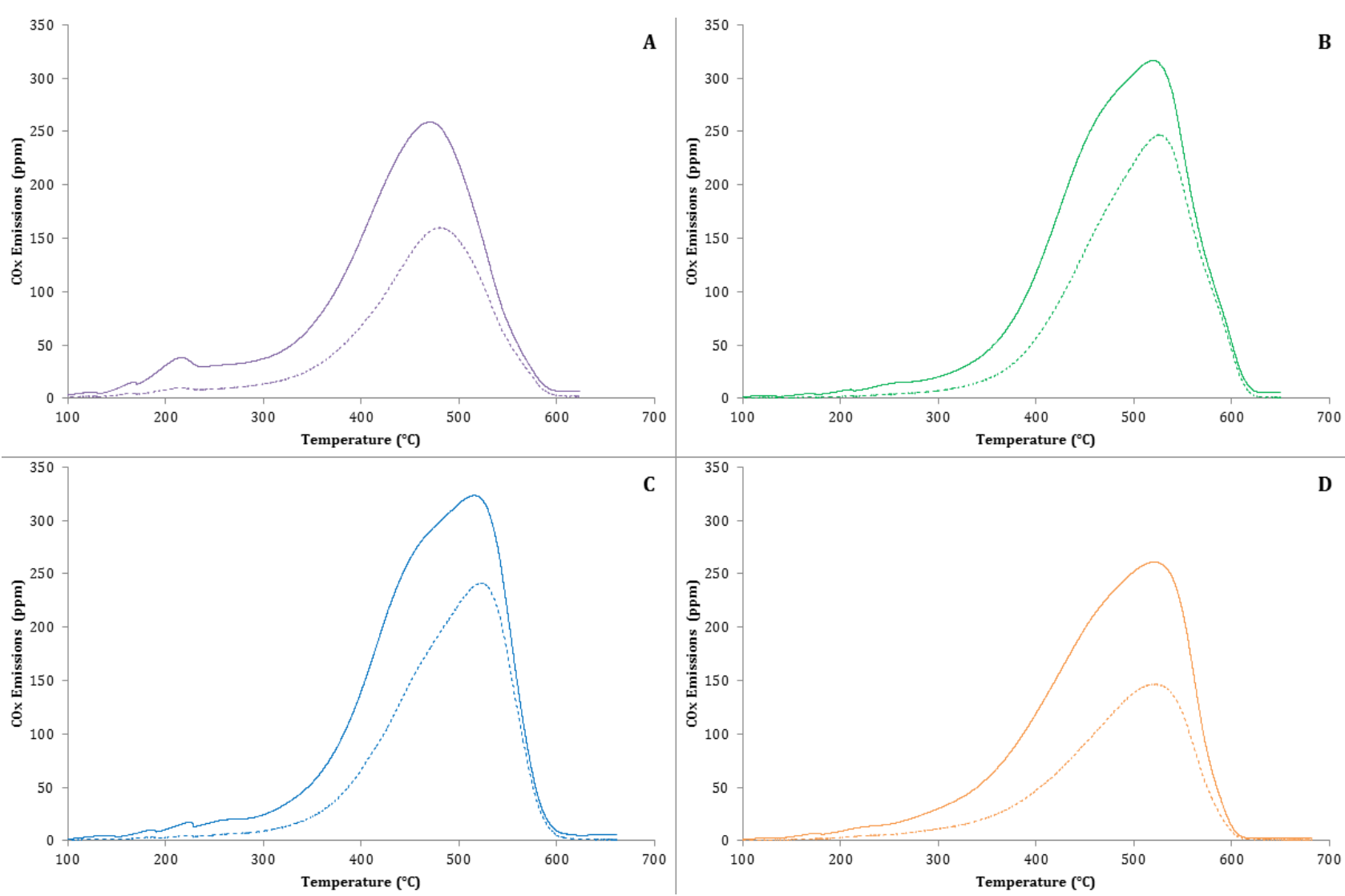

Figure 13 : $\mathrm{CO}$ (dotted line) and $\mathrm{CO}_{2}$ (full line) emissions for different soot samples under $\mathrm{NO}_{2}+\mathrm{O}_{2}$ : Aref soot (A -purple), MD30 soot (B - green), MD7 soot (C - blue), B7-BM-CA soot (D - orange). 